\title{
LA BOETIE VE SIYASAL KULLUK
}

\author{
Dr. Mehmet Ali AĞAOǴullaRI
}

\section{GiRİ}

Son yıllarda Fransa'da yeniden "keşfedilmeye" başlanan bir 16. yüzyıl düşünürü var: Etienne de La Boétie ve yapitı Discours sur la Servitude Volontaire (Gönüllü Kulluk Üzerine Söylev). ${ }^{2}$ Uzun süre derin bir unutkanlığın içine gömülmüş olan bu küçük yapıțın, bugün "siyasal düşünceler tarihi" uzmanlarınca öneminin kavrandığını ve hakkettiği yere oturtulduğunu gözlęmliyoruz. Yakın dostu büyük Fransız düşünürü Montaigne'in "Kanımca, La Boétie çağımızın en büyük insanıdır" diye söz ettiği bu düşünürün unutkanlık çemberini kırması, ancak yapıtının yeniden bir yorumlama-çözümleme süzgecinden geçirilmesiyle mümkün olmuştur. Yapit, yüzyıllar boyunca militan bir çerçeve içine konmuş ve bu açıdan değerlendirilmiştir. Siyasal çatışmaların ekseni ve niteliği değiştikçe, Söylev'e atıfta bulunup onu kendi görüşleri doğrultusunda kullanan yeni siyasal güçler belirmiştir. Fransız Calvincileri olan Huguenot'lardan cumhuriyet yandaşlarına, 1789 devrimcilerinden 19. yüzyllın "yükselen" proletaryasına değin çeşitli güçler, Söylev'i kurulu düzene, siyasal iktidara karşı çıkış duygularını dile getirip pekiştiren bir yapıt olarak algılamıslar ve onu bu yönde okumuşlardır. İçerdiği temel siyasal görüşleri fark edilememiş olan Söylev, sonuç olarak, her militan risalenin, her siyasal hiciv yazısının başına gelenle karşılaşmış, yani unutkanlığın içine düşmüştür.

Oysa La Boétie, döneminin somut koşullarından bağımsız, çağının çok ilerisinde bir yapıt oluşturmuştur. Fakat bununla, La Boétie'nin çağının ve toplumunun dışında, onlardan soyutlanmış bir biçimde düşünce ürettiğini söylemek istemiyoruz. $\mathrm{O} d a$ her düşünür gibi, döneminin toplumsal

$1 \mathrm{Bu}$ yapıtın tarafımdan yapılmış olan Türkçe çevirisi, Siyasal Bilgiler Fakültesi Dergisi'nin Ocak-Aralık 1983, No. 1-4 sayısında, 248-275 sayfaları arasında yayımlanmıştır. Makale boyunca Söylev'den aktarılan alıntıların ayraç içinde belirtilen sayfa numaraları, sözü edilen bu çeviriye gönderme yapmaktadır. Ceviri metnindeki birkaç yanlışın alıntılarda düzeltilmesi yoluna gidilmiştir. 
ve siyasal olgulamndan hareket etmiştir. Bununla birlikte, oluşturduğu siyasal düşünceler, bugünün insanını da doğrudan ilgilendiren temel sorunlara değindiklerinden dolayı; tarihsel boyutlarını aşıp bize kadar ulaşmışlardır. Bu olgu, bir bakıma düşüncenin belli bir "göreceli özerklik" taşımasından ileri gelmektedir. Bunun içindir ki, bir Platon, bir Machiavelli ya da bir Hobbes, düşüncelerini, içinde bulunduklam zaman ve mekân kesitinin sinırlamalarından kurtarmışlar ve onlara "evrensel" bir nitelik kazandırmışlardır. Bu düşünürler, toplumlarına özgü sorunları kendi görüşleri doğrultusunda çözmeye ugraşırlarken siyaset alanına genellemeler çerçevesinde yaklaşmışlardır. Siyaset olgusunu, tarihsel süreç içindeki belli bir toplumun ve o toplumun insanı açısından değil de, zoon politikon'la, yani "siyasallaşmıs" insanla birlikte ortaya çıkan genel siyasal sorunlar açısından ele almışlardır.

La Boétie, bu özelliğe sahip olmaktan da öte, sözünü ettiğimiz düşünürlerden farklı olarak militan bir tutum takınmamıştır; Söylev'i siyasal arenada çarpışan taraflardan birini desteklemek amacıyla kaleme almamıştır. Yapıtı ne tiranlığın ya da monarşinin yergisi, ne de cumhuriyetin ya da demokrasinin övgüsüdür. Söylev'in hemen başında, La Boétie, çeşitli hükümet biçimleri üzerinde tartışmak istemediğini, monarşinin öteki rejimlerden daha mı iyi, yoksa daha mi kötü olduğu sorunuyla ilgilenmediğini belirtir. Bunu söyleyerek, yapıtının sinırlamn ortaya koymaya çalıştığı sanılmasın. Tam tersine La Boétie, siyaseti geniş anlamı içinde ele alarak onu kendine konu edinir; bir başka deyişle, siyasetin şu ya da bu dıs görünümünü değil, fakat doğrudan doğruya siyasetin özünü açılamaya yönelir.

Siyaset olgusunu iktidar ilişkileri biçiminde algılayan La Boétie, bugün bile kafaları kurcalayan, "insanların nasıl olup,da itaat ettikleri, üstelik itaat etmekle kalmayıp boyun eğmeyi, hatta kulluk etmeyi arzuladıkları" sorununu yapıtının odak noktasına yerleştirir. Onun için, siyaset üzerinde düşünmek, yönetilenler durumunda olan insanlarm bu durumda kalmak istemelerinin nedenlerinin araştırılması olmaktadır. Fakat La Boétie, iktidar olgusunu ve bunun ideolojik dayanaklarmı (geniş anlamda hegemonyayı) irdelemekle yetinmez; iktidar ilişkileri ağının en üst düzeyde kurumsallaşmış biçimine, bir başka deyişle devlet sorununa yönelir. Tiranın ya da "Bir"in iktidarından yola çıkarak 16. yüzyıl Fransa'sında artık açlkça belirginleşmeye başlayan modern devletin gerçeğine ulaşır. Bu bakımdan Gönüllü Kulluk Üzerine Söylev, gerçekte, devlet iktidarının özü üzerine, (kavram La Boétie tarafından kullanılmamış olsa da) devlet egemenliğinin niteliği üzerine yapılmış bir söylevdir.

Söylev'i, yukanda belirtilen temel kavramlar (yani, iktidar, hegemonya ve devlet) çerçevesinde üç ayrı bölüm olarak irdeleyip yorumla- 
maya geçmeden önce, gerek La Boétie gerekse yapıtının tarihçesi hakkında kısa bilgiler vermenin, yazımıza açıklık kazandırmak için gerekli olduğu kanısindayız.

\section{YAZAR VE YAPITI}

Etienne de La Boétie, 1 Kasım 1530'da Fransa'nın Périgord bölgesinin küçük bir kenti olan Sarlat'da doğmuştur. Soylulaştırılmış burjuva kökenli olan La Boétie, ailesinin etkisiyle Orléans Üniversitesi'nde hukuk ögrenimi görmüşür. $O$ dönemlerde hümanizm ve reform akımlannın hukuk fakültelerinde yayılmış olduğu ve 1559 'da düşüncelerinden dolayı $\mathrm{Pa}$ ris'te yakılarak idam edilecek olan Protestan Parti'nin önde gelen "demokratlarından" Anne du Bourg'un Orléans'da hocalık yaptığı göz önüne alındığında, üniversite ylllamnın La Boétie'nin düşünsel gelişimi üzerindeki etkisi açıkça ortaya çıkar.

Fakülteyi bitirdikten bir yıl sonra, 1554'te, bu genç hukukçu, kral II. Henri'nin onayı üzerine Bordeaux Parlamentosu'nda danışmanlık görevine kabul edilmiştir. Ölümüne dek bu görevi sürdüren La Boétie, 1557 yılında kendisi gibi danışman olan Montaigne ile tanışmıştır. Bu iki düşünür arasında çok yakın bir dostluk ilişkisi kurulmuştu. ${ }^{2}$ Uzun bir süre Bordeaux Parlamentosu'nda etkin olamayan La Boétie, 1560 yılından başlayarak önemli görevler üstlenmiştir: Paris'te tanıştığı ana kraliçe Catherine de Médicis'in baş danışmanı Michel de l'Hospital'in düşüncelerini benimsemiş, bu düşüncelerin ve bu düşünceler doğrultusunda yayımlanan kraliyet fermanlarının Bordeaux yöresinde uygulanmasına çalışmıştır.

16. Yüzyıl Fransa'sının içinde bulunduğu en önemli sorun din çatı̧̧malarıydı. Monarşi, bir yandan krallı̆̆ı zayıflatan Katolik-Protestan çatışmasına çözüm arıyor, öte yandan kiliseye olan üstünlüğ̈ünü pekiştirmeye uğraşıyordu. İki aşırı ucu oluşturan Katolik Parti ile Protestan Parti'nin (Huguenot'ların) karşisına Michel de l'Hospital'in başını çektiği Politikler Partisi çıkmıştı. Dinsel hoşgörü taraftarı olan Politikler, Katolikliğin devlet dini kalmasını, Protestanlar için ibadet özgürlügünün güvence altına alınmasını ve monarşinin erkini arttırarak kilisenin ona ba-

2 Montaigne, "Denemeler" adh yapıtının 1. kitabındaki dostluk üzerine olan 28. bölümü La Boétie'nin anısına kaleme almıştır. Bu bölümün çeşitli yerlerinde La Boétie'den şöyle söz ettiği görülür: "Onsuz yorgun ve bezgin sürüklenip gidiyorum; tattığım zevkler bile, beni avutacak yerde ölümünün acısını daha fazla arttırıyor. Biz her şeyde birbirimizin yarısı idik; şimdi ben onun payını çalar gibi oluyorum... Ne yapsam, ne düşünsem onun eksikliğini duyuyorum. $O$ da benim için olbette aynı şeyi duyardı. Çünkü o, diğer bütün değerlerinde. olduğu gibi dostluk duygusunda da benden kat kat üstündü." Montaigne, Denemeler, Istanbul, Cem Yayınevi, 1980 (Türkçesi: Sabahattin Eyüboğlu). 
ğımlı kılınmasını savunuyorlardı. İşte bu düşüncelere katılan La Boétie, Protestanlara ibadet özgürlügü tanıyan 17 Ocak 1562 tarihli "Ocak Fermanı"nı savunan bir yazı da yazmıştır. Bu yazısında, mezhep savaşlarının tehdit ettiği ulusal birliği korumak kaygisiyla mutlak monarşi düşüncesine yaklaşmaktadır. La Boétie, daha 33 yaşına basmadan 14 Ağustos 1563 'te Germignan kasabasında ölmüştür.

Bir Rönesans insanı olan La Boétie'nin kısa yaşamı boyunca Ksenophon, Plutarkos ve Aristoteles'ten yaptığı çevirilerle yazdığı şiirler, ölümünden sonra 1570'te Montaigne tarafindan yayımianmıştır. Montaigne, La Boétie'nin bu Rönesans esinli yapıtları dışında Söylev'in el yazmasına da sahipti. Çeşitli yazışmalarında, Söylev'i yazacağı kitabın (yani Denemeler'in) en önemli parçası olarak kullanmays düşündüğünü belirtmiş, ancak daha sonralar bu tasarısından vazgeçmiştir. Bunun nedeni, bu yapıtın, bugün de açıklığa kavuşamamış bir biçimde Huguenot militanlarca ele geçirilip yayımlanmış olmasıdır.

1572'deki Saint-Barthélemy kıyımından sonra Huguenot'lar arasında, siyasal iktidara karşı artık edilgen değil de etkin olarak direnmek gerektiğine, baskıya başkaldırmanın ve tiranın öldürülmesinin (tyrannicide'in) meşru olduğuna ilişkin görüşler yayılmaya başlar. Bu görüşleri savunmak için ortaya çıkan "monarkomaklar" diye bilinen Protestan düşünürlerin yazıları yanında, daha önceleri yazılmıs olmalarına karşın hemen hemen aynı temaları içeren yapıtlar da Calvinci militanlarca benimsenip kullanılır. İşte bu yapitlardan biri de La Boétie'nin Söylevi'dir. İlk olarak, 1574'te Söylev'den alınan bazı parçalar, yazarının adı verilmeden, çeşitli yergi yazılarını içeren Le Réveille-matin des François (Fransızların Çalar Saati) adlı kitapta yayımlanır. Bundan iki yıl sonra, Söylev, yine aynı nitelikte bir kitap olan Mémoires des Etats de France sous Charles le Neuvièsme'de (Dokuzuncu Charles Dönemi Fransa Devletleri Üzerine Savlar'da), bu kez bütünüyle ve La Boétie'nin adı belirtilerek Contr'un (Bir'e Karşı) başlığıyla yer alır. İık baskısı Cenevre'de yapılmış olan bu kitap, daha sonraları 1577 'de ve iki kez olmak üzere 1578'de yeniden basılır.

Bu dönemde, Söylev'in bazı Protestan düşünürler için esin kaynağı oluşturduğunu da belirtmek gerekir. Bu olguyu en açık bir biçimde Stephanus Junius Brutus takma adıyla 1579 yılında İsviçre'de yayımlanan Vindiciae contra Tyrannos (Tiranlara Karşı Direnme Hakkı) başlıklı risalede görmek mümkün. Bu risalenin yazarı olduğu sanılan Hubert Languet ya da Philippe du Plessis-Mornay, La Boétie'den farklı olarak, feodal değerlere ağırlık vermiş ve görüşlerini doğrulamak amacıyla bol bol dinsel içerikli örnekler kullanmıştır. Bununla birlikte, yazarın Söylev'i dikkatlice okuyup, bunun özellikle "retorik"inden epey etkilenmiş olduğu an- 
laşılıyor: Söylev'deki bazı parçalar, hatta bazı çarpıcı tümceler hemen hemen olduklan gibi alınıp Vindiciae'ye aktanlmıştır.

Din savaşlarının yaygınlaşıp keskin boyutlar kazandığı bu dönemde, Huguenot'larn Söylev'i kendi amaçlarına uygun bulup bu doğrultuda yayımlamalar, La Boétie'nin yüzyıllar sonra da monarkomak olarak tanınmasına neden olmuştur. Çağımızın siyasal düşünce tarihçilerinin bu yanlı̧ kanıdan kurtulmalan pek kolay olmamıştır; üstelik içlerinden bazılar bu görüşe saplanıp kalmışlardır. Yavuz Abadan, 1959 yilında yayımlanmış bir ortak yapıtta, kısaca değindiği La Boétie'den Huguenot diye söz eder ve onun mutlak monarşi kuramlarına karşı halk egemenliğini savunduğunu belirtir. ${ }^{4}$ Fransa'da ise, 1980 yllında yedinci baskısını yapmıs olan önemli bir siyasal düşünceler kitabı, La Boétie'nin Protestan olmadığını vurgulamasına karşın onu yine de monarkomaklar arasına yerleştirmektedir. ${ }^{5}$ Ölümünden yillar sonra Amerikan ve Fransız devrimcileri tarafından kullanıldı diye Montesquieu'yü bir demokrasi kuramcısı olarak görmek ne kadar yanlıssa, La Boétie'ye monarkomak etiketini yapıştırmak da o derece yanlış olur kanısındayız.

La Boétie'nin, siyasal düzeni şiddet yoluyla yıkmayı saviunan Huguenot'lara yakın bir düşünür biçiminde değerlendirilmesine ilk karşı çıkan Montaigne olmuştur. İlk önce Calvinci olarak kabul edilmemek için Söylev'i yayımlamaktan vazgeçen Montaigne, daha sonra La Boétie'nin bunu neden yazdığını açıklayarak arkadaşının adını temize çıkarmaya

${ }^{3}$ Söylev ile Vindiciae arasındaki benzerliği vurgulamak için her iki yapıtta da geçen bir kaç tümceden örnek vermek yeterli olur kanısındayız: Söylev: “... Eğer siz vermediyseniz, sizi gözetlediği bu kadar çok gözü nereden buldu? Eğer sizden almadıysa, nesıl oluyor da sizleri dövdüğü bu kadar çok eli olabiliyor?... Kulluk etmemeye karar verdiğiniz an özgürsünüz demektir. Onu itmenizi ya da dengesini bozmanızı istemiyorum. Fakat yalnızca onu desteklemeyin; işte o zaman, onun altından temeli (kaidesi) çekilmiş bir Colosse (Rodos'taki koca Apollon heykeli) gibi tüm ağırlığıyla düșüp parçalandığını göreceksiniz. Kendi kendini kulluklaştıran, kendi boğazını kesen halk..."

Vindiciae: “... Ve neden "Kralların sayısız gözleri, milyon tane kulağı, upuzun elleri ve pek hızlı ayaklar" olduğu söylenir... Halk kralı yüzüstü bırakıversin, hemen yere devrilir... Bu devin temelini altından çekin, Rodos'taki koca Apollon heykeli (Colossus) gibi ayakta duramaz, devrilip paramparça olur... Bir halkun kendini kelepçe ve zincirlere vurmasından... kendi el ve silảhlariyla kendi kendilerinin celládı olmak zorunda kalmasından..." Vindiciae contra Tyrannos'un türkçe çevirisi: Mete TUNÇAY (derleyen), Batida Siyasal Düşünceler Tarihi, Seçilmiş Yazilar, Ankara, A.U. Siyasal Bilgiler Fakültesi Yayınlar, 1969, Cilt II, 5. 61-87.

- ABADAN Yavuz (derleyen), Devlet Felsefesi, Seçilmis Okuma Parçaları, Ankara, A.U. Siyasal Bilgiler Fakültesi Yayınlar, 1959, s. 179.

5 PRELOT Marcel et LESCUYER Georges, Histoiro des idées politiques, Paris, Dalloz, 1980, s. 255-257. 
çalışır: “"Gönüllü Kulluk” adı verdiği bu söylevi, ilk gençlik çağlarında, tiranlara karşı özgürlüğü yücelten bir deneme biçıminde yazmıştır. Sonraları bu yapıt, iyi diye salık verilemiyecek kişilerin eline geçmiştir... Ülke güvenliğini bozmak ve düzeni değiştirmek isteyen bu kişiler, söylevi kötü amaçları doğrultusunda kullanmak için gün ışığına çıkarmışlar ve onu kendi düşüncelerini içeren yazılarin arasına- katmışlardır. Yazarın anısı, onun düşüncelerini ve eylemlerini yakından tanımayanlar tarafından rencide edilmemesi için, bu konunun çocukluk çağındaki yazar tarafından sıradan ve çok yinelenmiş bir konu olarak kabul edilip, salt alıştırma, deneme olsun diye ele alındığını belirteceğim." Montaigne, La Boétie'nin monarkomaklarla aym kaba konmasını önlemek amacıyla Söylev'in içerdiği radikal düşünceleri göz ardı ederek, onun yalnızca tiranlığı yermek için kaleme alındığını ileri sürmek zorunda kalır. Böylece La Boétie'nin daha sonraları yanlış yorumlanmasına neden olacak kapıyı açmış olur. Üstelik, arkadaşının anısını her türlü karalamadan uzak tutma kaygisıyla hareket eden Montaigne, La Boétie'nin kişiliğini çarpıtarak, onu bir tutucu, kurulu düzenle özdeşleşmiş bir kişi olarak tantacak kadar ileri götürür savunmasını: "Onun ruhuna işlemiş bir kuralı vardır: Doğduğu yerin yasalarına körü körüne itaat etmek... zamanın kargaşalıkLarına ve yeniliklerine ondan daha düşman olan bir başka kişi düşünülemez." Yine de Montaigne, La Boétie'nin bir Rönesans insanı olduğunu ve dinsel hoşgörüyle cumhuriyeti benimsediğini üstü kapalı bir biçimde de olsa belirtmeden edemez: "Eğer seçmeye olanağı olsaydı, haklı olarak Sarlat yerine Venedik'te doğmayı isterdi... Onun düşüncesi, dönemindeń çok başka çağların düşünce kalıplarına göre yoğrulmuştu."

La Boétie, Söylèv'i gerçekten gençlik yıllarında, 16-18 yaşları arasında mı yazmıştır? Yoksa Montaigne, bu savı dà, yukarıda belirttiğimiz diğer savlar gibi, arkadaşın kollamak, yani Söylev'in "bir "gençlik günahı" olduğunu dolaylı bir biçimde anlatmak için mi ileri sürmüş̧ür? La Boétie'nin Söylev'i 1546-1548 yılları arasında kaleme aldığı kabul edilse bile, yapıtını daha sonra yeniden gözden geçirdiği bugün kesinlik kazanmıştır. Bazı araştırmacılar, La Boétie'nin büyük bir olasılıkla, Fransa'nın güney bölgelerinde patlak verip 1549 'da kraliyet güçlerince kanl bir biçimde bastırılan (tarihte Gabelle ayaklanması adıyla bilinen) köylü ayaklanmasından etkilenmiş olabileceğini belirtirler.? La Bótie, Söylev'de bu olay-

- Montaigne'in La Boétie hakkındaki, içinden bölümler aktardığımız bu yazılarn. Denemeler yapıtının 1. kitabının 27. bölümünde yer almaktadır.

7 Bu görüşü, ilk kez, Montaigne'in arkadaşı olan Jacques-Auguste de THOU, "Histoire de son temps" adlı yapıtında ileri sürmüştür. Miguel ABENSOUR ile - Marcel GAUCHET de, Etienne de la Boétie, Le Discours sur la Servitude Volontaire, Paris, Payot, 1978'in giriş bölümünde aynı görüşü paylaşmaktadırlar. 
dan hiç söz etmemiş olmasına karşın, tarihte ilk kez bu köylü ayaklanmasının senyörlere karşı değil de, devlete karşı bir başkaldırı biçiminde geliştiğinin bilincine varmıştır. Bu nedenle yazar, yapıtında, köylülerin tepkisini çeken, toplumun en uç köşelerine kadar girerek varlığını her yerde hissettiren ye yerel özgürlükleri, ayrıcalıkları yıkan iktidar aygıtını, bir başka deyişle modern devlet gerçeğini açıkça dile getirip eleştirebilmiştir.

La Boétie, 1553 yılında Orléans'da iken yapıtına önemli değişiklikler ve eklemeler getirmiştir. Bu görüşü kuvvetlendiren kanıt, Söylev'de Ronsard, Du Bellay gibi şairlerden söz edilmiş olmasıdır. İlk yapıtlarırı 15491550 yıllarında yayımlayan bu şairler, ancak 1552 'den sonra tanınmaya başlamışlardır. Bu bakımdan, bu şairlerle ilgili bölümün, Söylev'in 15461548 yıllarında yazıldığı varsayılan ilk metninde bulunmadığı ve daha sonradan eklendiği ortaya çıkmaktadır. Bundan başka La Boétie'nin, Orléans' Üniversitesi'nde hocası. olan Du Bourg'un "demokratik". düsünceleriyle şiddetinden etkilendiği ve gençliğinde yazdığı bu denemeyi hocasının görüşleri doğrultusunda geliştirdiği de olası gözükmektedir. Söylev'in yazılış tekniğine, içerdiği görüşlere ve bunların tutarlılığına, Eski Yunan ile Roma tarihinden getirilen örneklere bakıldığında ise, yapitın olgun bir kişi tarafından yazıldığı anlaşılmaktadır. Demek ki Söylev, Montaigne’in ileri sürdüğü gibi "düşüncesiz gençlik çağlarının" bir ürünü değildir. Söylev'i yazan, bilinçli bir biçimde ileri sürdüğü görüşlerin sorumluluğunu taşıyan ve bunlara yürekten inanan olgun bír La Boétie'dir.

Fakat La Boétie, yapıtındaki görüşleri sịyasal yaşamında uygúlamamıştır. Söylev dikkatlice incelendiğinde, La Boétie'nin yapıtını kendinden emin, düşüncelerinin yakın bir gelecekte uygulanacağına güvenen bir tonda yazmadığı görülür. Söylev bir bakıma, güzel bir ideale sahip, ancak tarihsel koşulların bunun gerçekleşmesine olanak vermeyeceğini sezen genç bir aydinın çaresiz tutumunu yansitır. Gerek kişiliği ve toplumsal çevresi, gerekse Fransız siyasal çatışmalarının keskin boyutları, La Boétie’nin düş dünyasına dalıp ütopyaya kaymasını önlemişlerdir. Bụndan dolayı bu genç aydın, moral bir başkaldırıya sı̆̆ınmış ve görüş̧lerini kağıt üzerine dökmekle yetinmiştir. Kısa bir süre sonra bu edilgin muhalif tutumunu terkeden La Boétie, yerdiği devlet aygitının çarklarında görev almıştır. Bu yönüyle Thomas More'u anımsatır: Siyasal yaşamın dışında kalıp hiçbir şey yapamamaktansa, gerçekçi olup, en azından toplumdaki büyük kötülükleri azaltmak için iktidar piramidinde bir yer edinmek ve bu doğrultuda çaba harcamak. La Boétie, bu tásarisını uygulamaya koyarken siyasal alandaki taraflardan birinin, politiklerin (dolayısiyla burjuvazinin) görüşlerine yak̈laşır; bir başka deyişle, feodalizme ve dinsel bağnazlığa karşı koyabilecek ve mezhepler arasında hoşgörüyle barışı sağ- 
layabilecek tek güç olarak gördüğü monarşiye destek olur. ${ }^{8}$ Fakat La Boétie bu. konuda, kendisinden iki yüzyıl sonra Montesquieu'nün de yapacağı aynı yanılgının içine düşmektedir. ${ }^{9}$ Çünkü monarşi, mutlak olsun ya da olmasın, niteliği gereği feodal toplumsal düzene ve ideolojisini aldığı. kiliseye sıkı sıkıya bağlıdır. Zaten, La Boétie'nin ölümünden dokuz yıl sonra, Saint-Barthélemy kıyımı ile dinsel bağnazlığın tarihteki en kanll örneğini veren yine La Boétie'nin dinsel hoşgörüyü gerçekleştireceğine inandığı bu Fransız monarşisi değil midir ki?

Din çatışmalarının yatışmasıyla birlikte Söylev, göreli bir unutkanlığın içine düşmüş; yalnız dönemin "tehlikeli" sayılan kişileri arasında ve iktidar çevresinde el altından dolaşmıştır. Örneğin Richelieu, Söylev'i uzun süre aratmış ve sonunda büyuk paralar vererek bir kitap kolleksiyoncusundan 'satın alabilmiştir. Söylev'in ikinci kez gündeme gelip yeni baskılarının yapılması, cumhuriyet için, demokrasi için, verilen savaşların yoğunluk kazanmasıyla başlar. Bu kez demokrasinin övgüsü olarak değerlendirilen ve bu açıdan okunan Söylev'in Fransız Devrimi'nin ilk yıllarında iki ayrı kitapta yer aldığını görüyoruz. Daha sonraları yapıt, 1835'te mistik ve hümanist bir sosyalist olan Félicité de la Mennais tarafından yayımlanmıs.' Son olarak da, 1857'de Louis-Napoléon'un darbesi üzerine Brüksel'e kaçan cumhuriyetçiler Söylev'in basımını gerçekleştirmişler. Siyasal alandaki çatışmaların salt politik olmaktan çıkıp, sosyoekonomik bir içerik kazanmaları (daha doğrusu, bu çatışmaların sosyo-ekonomik temellerinin ortaya konulup kitlelerce anlaşılması) sonucunda Söylev, bu yeni ortamda militan bir yapit biçiminde değerlendirilemediğinden dolayı, tarih dışı (anachronique) kalarak önemini yitirmiş ve günümüze dek süren ikinci bir göreceli unutkanlık döneminin içine girmiştir. Yapıtın bugün yeniden gün ışı̆ına çıkması ise, 70'li yıllarda Fransa'da "iktidarın, devletin (fiziksel ve ideolojik) baskıcı, otoriter özü" sorununu ortaya koyup araştırma konusu edinen entellektüel bir akımın belirmesi ve La Boétie'nin bu yönde yeniden okunmasiyla mümkün olmuştur.

\section{IKKTIDAR}

Söylev'in yüzeysel bir okunuşu, bu yapitın tiranlığın bir yergisi biçiminde algılanmasına neden olabilir. Oysa, yukarıda belirttiğimiz gibi

${ }^{8}$ Le. Boètie, bu görüşlerini 1562 yılında yazdığı Ocak Fermanı ile ilgili yazısında (Mémoire touchant l'Edit de Janvier) dile gețirmiştir. La Boétie, OEuvres Politiques, Paris, Editions Sociales, 1971, s. 81-92.

9 Monarkın burjuvaziyle işbirliği içinde soyluları ezmeye ve feodal yapıyı yıkmaya yöneldiği yargısına varıp monarşinin sınırlanmasın savinan Montesquieu, bu yanılgısı nedeniyle monarşinin, dolayısıyla yandaşı olduğu soylulann yıkılışına düsünsel düzeyde katkıda bulunmuş olur. Bu konuda daha geniş bilgi için bkz.: Louis ALTHUSSER, Montesquieu, La politique et l'histoire, Paris, PUF, 1959. 
La Boétie'nin amacı, herhangi bir siyasal rejimin yergisini ya da övgüsünü yapmak değildir. Üstelik, siyasetin ne olduğunu açlklamaya yönelen La Boétie, tüm siyasal rejimlerin ya da tüm siyasal iktidar biçimlerinin aynı kapıya çıktıkları, yani hepsinin kötü oldukları inancını taşımaktadır. Fakat böylesine olumsuz bir görüşü benimseyen yazarmn "radikal bir anarşist" tutumu takınarak her türlü yetkeyi (otoriteyi) yadsldığı sanılmasın. Örneğin, aile içinde oluşan iktidar ilişkilerine karşı değildir; dahası, aile büyüklerine itaat etmenin insanın doğal yapısından kaynaklandığını ve aklın buyruğuna uygun düştüğünü açıkça belirtmektedir.

La Boétie'nin irdeleyip büyük bir kötülük olarak betimlediği iktidar, toplumdaki bireylerin tümü üzerinde etkisini hissettiren ve toplumun yazgısını belirleyen iktidardır; bir başka deyişle siyasal iktidardır söz konusu olan. ${ }^{10}$ Ancak, siyasal antropolojinin bulguları göz önünde bulundurulduğunda, Söylev'de sözü edilen siyasal iktidar olgusunun (özellikle 16. yüzyıl bilgi birikiminin yetersizliğinden dolayı) sinırlı bir alan içine oturtulduğu ya da daha doğrusu bunun yalnızca belli bir düzeyinin ele alindığı görülür. Günümüz antropologlamnın büyük bir bölümü, siyasetin (ve buna bağımlı olarak siyasal iktidamn) bütün toplumsal formasyonlara içkin olduğu görüşünde birleşmektedirler. ${ }^{1}$ Pierre Clastres'ın "(siyasal): iktidarın bulunmadığı toplum yoktur" deyişi; bu görüşü çok açık bir biçimde özetlemektedir. ${ }^{12}$ Her türlü toplumsal yaşam, siyasal iktidar ilişkilerini zorunlu olarak yaratmakla birlikte, bu ilişkilerin aldıklam biçimler büyük farklılıklar gösterir. Örneğin, özellikle "ilkel" toplumlara özgü farklılaşmamış, dağınık siyasal iktidarla belli bir merkezde toplanıp kurumsallaşan siyasal iktidar arasında bir benzeşim kurmak epey güçtür. Soruna bir açıklık getirmek için Jean-William Lapierre'in yapmı̧ olduğu dokuz ayrı siyasal iktidar düzeyi sinıflandırmasından yararlanılabilir: ${ }^{13} \mathrm{La}$ Boétie'nin siyasal iktidar anlayışı sekizinci düzeye uygun düşmektedir. $\mathrm{Bu}$ düzeyde toplumsal erk, (meşru şiddet kullanımı biçiminde) hükmedenlerin elinde toplanmış ve uzmanlaşmı̧ bir hükümet aygıtı belirmiş-

$\overline{10}$ La Boétie, yapıtında "siyasal iktidar" kavramını kullanmamıştır. Bu olguyu, yönctenler açısından "güç" (puissance) ya da yalnızca "iktidar" (pouvoirl, yönetilenler bakımindan ise "gönüllü kulluk" (servitude volontaire) olarak adlandurmiștır.

11 Georges BALANDIER, Anthropologie Politique, Paris, PUF, 1969, S. VIII.

12 Pierre CLASTRES, La Société contre l'Etat, Paris, Minuit, 1974, s. 21.

13 Jean-William LAPIERRE, Vivre sans Etat?, Paris. Seuil, 1977, s. 75-153. Lapierre, Clastres'in görüşünü paylaşarak her toplumda siyasal iktidarn bulunduğunu savunur, fakat ondan farklı olarak en "ilkel" siyasal iktidar biçiminin bile şiddcti içerdiğini kabul eder. Bu iki kitabın karşılaştırmalı tanıtımı için bkz.: Mehmet Ali AĞAOG̈ULlARI, "Devietsiz Olmak ya da Olmamak", in Yapıt, No. 5, 1984, s. $102-109$. 
tir; yani siyasal iktidar kurumsallaşmıs ve "egemen" devlet ortaya çımıştır. Bú açıdan değerlendirildiğinde, La Boétie'deki siyasal.iktidarın "modern-egemen" devletle özdeşleşmiş olduğu anlaşllır. Bu nedenle, La Boétie'nin (genel anlamda) siyasal iktidarın değil, fakat yönetenler-yönetilenler ayrımını belirginleştiren devlet iktidarının özünü açıklamaya çalıştığını söylemek daha doğru olacaktır.

Söylev'in başlangıcında bulunan Homeros'un iḳi dizesinden ilkini, * Aristoteles de Politika adlı yapıtında çeşitli yönetim biçimlerini incelerken kullanmıştır. ${ }^{14}$ Aristoteles bunu, iktidarın halkta olduğu, yasalamn bulunmadığı bir demokrasi biçiminde yorumlamaya yatkın görülmektedir. Böylece, iyi ve kötü rejimleri birbirlerinden ayırt etmeye yarayacak bir ölçütü, yani yasa kıstasını ortaya koymaktadır. Oysa La Boétie, hem yasa hem de otorite ölçütlerine baş vurmadan bütün rejimlerdeki hükmetme sorunu üzerinde durur. Machiavelli'yi andırır bir biçimde, klasik düşüncede başat olarak kabul edilen "karşıt rejimler" olgusunu önemsemez. Machiavelli için siyasal iktidar ya vardır ya da yoktur; var olduğu anda ise meşrudur. $\mathrm{Bu}$ bakımdan, bu alanda iyi-kötü gibi ahlaki bir sınıflandırma yapmak gereksizdir. ${ }^{15}$ La Boétie ise aynı görüşten hareket edip çok farklı bir sonuca ulaşır. Ona göre haklı gösterilebilecek hiçbir siyasal rejim yoktur, hepsi kötüdür. Hükmetme yetkisinin bir tek kişinin ya da bir §̧oğunluğun elinde bulunmasının, iktidar sahiplerinin bu konumlarını ister fetih ya da kalıtım yoluyla, ister halkın seçimi sayesinde elde etmiş olmalarının en ufak bir önemi yoktur. Çünkü siyasal iktidarın özü hiçbir zaman değişmez; biçimi ne olursa olsun, özü tiranlıktır hep.

La Boétie'nin böyle bir saptamada bulunduğuna bakılarak onun siyaset alanını özerk bir biçimde ele almadığı sonucuna varmak yanlış olur. Söylev'de siyaseti dinsel ya da ahlaki temeller içine oturtan geleneksel yaklaşım terkedilmiştir. Siyasal iktidarın adlandırılamayacak kadar kötü bir şey olduğu vurgulanarak bir değer yargısı getirilmesi, ahlaki kaygı-

\footnotetext{
* "Göremem hiçbir iyilik birçok efendinin olmasından"

14 ARISTOTE, La Politique, Paris, Editions Gonthier, 1977, s. 113. Politika'nun Mete Tunçay tarafindan yapılmıs olan Türkçe çevirisinde Homeros'un bu misrasına yer verilmemiş ve bu mısranın içinde yer aldığı tümce şöyle çevrilmiş: "Homeros'un kötü bir şey diye sözünü ederken, ne gibi bir çoklu-egemenliği anlatmak istediğini bilmiyorum; ortaklaşa $\mathrm{ml}$, bireysel mi?". ARISTOTELES, Politika, Istanbul, Remzi Kitabevi, 1975, s. 118.

Politika'nın Türkçesinde görülen bu eksiklik, Mete Tunçay'ın çeviri için kullan. dığı T'.A. Sinclair'in Ingilizce çevirisinden kaynaklanmaktadır.

${ }^{25}$ Gérard MAIRET, Machiavelli'de ahlak sorununun terkedilmediğini, bunun teorik alandan alınıp pratik alana yerleştirildiğini belirtir: "Böyleçe meşruluk, iktidarı elde etme ve onu koruma olgusu içine oturtulur." G. MAIRET, Les doctrines du pouvoir, Paris, Gallimard-Collection Idées, 1978, s. 94.
} 
ların sonucu değildir. Çünkü La Boétie için siyasette ahlaki olan ya da olabilecek hiçbir şey yoktur. Bundan dolayı, siyasal alana ahlaki kuralların uygulanması hiçbir sonuç getirmez; dahası sorunun özünün anlaşlmasına engel olur. Zaman ve mekân içinde değişen öznel kurallardan hareket ederek siyasetin (dolayisiyla siyasal iktidarn) nasıl olması gerektiğini saptamaya yönelmek, siyasetin ne olduğu gerçeğinin göz ardı edilmesinden başka bir şey değildir. İşte La Boétie, bu gibi görüşleri benimsediğinden dolayı, yapıtını metafiziksel ve ahlaki açıklamalardan anndırdığı gibi, kendini de ütopik çözüm yolları aramaktan alıkoyabilmiştir.

Bir Rönesans hümanisti olan La Boétie, Hobbes'un "bir şeyi iyi anlamak, o şeyi oluşturan parçaları iyice gözetmekle mümkündür"16 görüşüne koşutluk göstererek, siyasal iktidar incelemede ve değerlendirmede bu olguyu var kilan parçalardan, yani insanlardan hareket eder. İnsanın ne olduğu, ne gibi bir doğaya sahip bulunduğu sorunu yanitlanmadan, insan ilişkilerinin belli bir biçim altında sürmesi olarak beliren siyasal iktidarı ve bunun kurumsallaşmıs şekli olan devlet mekanizmasının işleyişini anlamak olası değildir. Bu bağlamda La Boétie, devleti doğal bir gerçek olarak kabul eden düşünceden bütünüyle ayrlmaktadır. Devletin bireylerden bağımsız bir varlığı olmadığından başka, insan da Aristoteles'in zoon politikon ${ }^{17}$ (siyasal hayvan) yakıştırmasına hiç uymaz. İnsan doğasında siyasallığa ilişkin hiçbir şey yoktur, yani siyasetin özünü oluşturan hükmetmeye ve özellikle boyun eğip kulluklaşmaya doğru bir eğilim bulunmaz.

La Boétie’ye göre insanın doğası özgürlüktür, özgür olmasıdır. Dahası insan, doğal yapısı gereğince, dünyaya gelirken özgür olduğundan başka özgürlüği koruma duygusuyla da bezenmiştir. Fakat Rousseau'nun "İnsan özgür doğar, oysa her yerde zincire vurulmuştur"18 saptamasını an-

16 Thomas HOBBES bu görüşünü De Cive adlı yapıtının giris bölümünde dile getirmiştir. Aktaran: François RANGEON, Hobbes, Etat et droit, Paris, J.E. HallierAlbin Michel, 1982, s. 51.

17 ARISTOTELES, op. cit., 5.9 .

18 Jean-Jacques ROUSSEAU, Toplum Sözleşmesi, Istanbul, Adam Y., 1982, s. 14. Rousseau'nun La Bośtie'yi okumuş olduğunu gösteren hiç bir bilgi yok. Bununla birlikte, ilk yapitlarında daha radikal bir tutum içinde olan Rousseau'nun özellikle Discours sur l'origine et les fondements de l'inégalité parni les hommes (Türkçeyo "İnsanlar Arașındaki Eşitsizliğin Kaynağı" adı altında çevrilmiştir) adlı kitabında iléri sürdüğü bazı savların ve kullandığı bazı örneklemelerin Söylev'dekilerle büyük bir benzerlik gösterdiği açıkça gözlemlenebilir. Söylediklerimizi kanitlamak için birkaç örnek getirelim: La Boétie'de özgürlüğgunü yitirmemek için gemi azıya alı mahmuza saldıran at imgesi Rousseau'da da bulunmaktadır. (Bkz. Discours sur l'origine..., Paris, Garnier-Flammarion, 1971, s. 233) Her iki düşünür de alışkanlı̆̆ın kulluklaşmayı (köleleşmeyi) güçlendir- 
dırnrcasına, La Boétie için de bu ilk, özgün özgürlük yitirilmiş, insan yozlaşmıştır. Bu yozlaşma öylesine büyük boyutlardadır ki, insan, değil özgürlüğünü korumak onu anımsamamaktadır bile. Üstelik boyun eğmeye rıza göstermekle kalmayıp, kulluğu sevip ona gönülden bağlanır. Özgürlïgünü yitiren bu insan, aynı zamanda insanlığını da yitirir, kendi benliğini yadsıdığı bir düzeye iner; doğasının değişmesi, yozlaşması sonucu bir hayvan bile değildir artık. Çünkü hayvanlar, insanlardan farklı olarak, özgürlüklerini hiçbir şeye karşı değişmedikleri gibi, onu karşı konulmaz bir gücün zorlamasıyla yitirseler bile bu kul-köle durumlarını hiçbir zaman benimsemezler, istemeye istemeye, sizlana sizlana hizmet ederler. Ozan La Boétie için "Öküzler bile boyunduruk altında sızlanır-Kuşlar ise kafes içinde yakınır." (s. 255)

Hayvanların böyle farklı bir konum içinde oluşlan, onlar ilgilendiren iktidar ilişkilerinin (yani kendi aralarında ya da insanlarla olan iktidar ilişkilerinin) siyasal bir nitelik taşımamalarından kaynaklanmaktadır. Buradaki ilişkiler yalnızca hükmetme-boyun eğme çerçevesi içinde gerçekleşir; bunların temelinde salt gü̧, fiziksel baskı bulunmaktadır. Bundan dolayı, hükmedilenlerden iktidarı onamaları, ona rı̣a göstermeleri beklen€mez. Oysa insanlar, kulluğu gönüllü olarak benimserler. Demek ki insan toplumlarında beliren iktidar biçimi, yalnızca baskı uygulamayla yetinmeyip kendini kabul ettirecek yeni ilişkiler de geliştirir: İdeolojik söyleme başvurarak meşruluğunu kanıtlar ve böylece hükmetme-boyun eğme iliş̧kilerinin yanına buyurma-onama ilişkilerini- de ekler. ${ }^{19}$

diği görüşünde birleşmektedirler. La Boétie'ye göre "halk bir kere kulluklaşmaya görsün (yani hizmet etme alışkanlığın edinsin) özgürlüğü öylesine unutuyor ki, artık onun uyanıp yeniden özgürlügünü ele geçirmesi olanaksız oluyor." (s. 257). Rousseau ise bu görüşü şöyle dile getirir. "Halklar bir kere efendilere alıştılar mi artık bunlardan vazgeçmeleri olanaksızlaşır" (s. 141). Iki düşünür arasındaki bir başka benzerlik, kulluklaşma (köleleşme) mekanizmasının işleyişinin açıklanmasında görülür. La Boètie için "tiran uyruklarını birbirlerine kırdırarak kulluklaştırır... Yükselme hırsıyla suçlandırılan bu kişiler... kötülüğe (yani kul-köle durumlarına) katlanmaktan hoşnutlar. Çünkü onlar da aynı kötülüğü, kendilerine bunu yapmış olan kişiye değil de, aynı onlar gibi kötülük görmüş olan, fakat başkalarına da benzerini yapamayan kişilere karşı uyguluyorlar:" (s. 270). Bu görüş Rousseau için de geçerlidir: "Yurttaşlar, kör bir yükselme tutkusuna kapıldıkça ve aşağısı yerine yükseklere baktıkça kendilerinin ezilmesine daha kolaylıkla rıza gösterirler; hükmetme onlar için bağımsızluktan daha fazla önem kazanır ve başkalarını zincir altında tutabilmek için kendileri de zincir taşımayı kabul ederler." (s. 229).

${ }^{19}$ Jean-William LAPIERRE siyasal iktidarı şöyle tanumlamaktadır: "Siyasal iktidar, toplumsal düzenlemenin gerçekleştirmesini sağlayan buyurma-onama (yetke) ilişkileriyle hükmetme-boyun eğme (gü̧) ilişkilerinin değişken bağdaşımıdir.: (LAPIERRE, op. cit., s. 16). Bu arada dogmatik marksizmin devleti yalnizca bir baskı aracı biçimindeki değerlendirmesinin de terkedildiğini belirtelim. An- 
Pierre Clastres'a göre siyasal iktidarın gerçekten var olabilmesi, "iktidar arzusunun kendisine gerekli olan boyun eğme arzusunu yaratmasina" băğldır. ${ }^{20} \mathrm{Bu}$ gerçeğin bilincinde olan La Boétie, siyasal iktidarnn var olụ işleyebilmesi için, hükmetme arzusundan çok gönüllü kulluk olgusunun yerleşmiş olması gerektiğini vurgulayarak siyasal alanda meşruluğun, ideolojik koşullanmanın (ya da koşullandı̨rmanın) ne kadar önemli bir yer tuttuklarnna dikkati çèker.

$\mathrm{Bu}$ konuya üçüncü bölümde daha aymntılı bir biçimde değinilecəktir. Şimdilik, buraya değin çözümlemeye çalıştığımız La Boétie'nin görüşlerinin mantıki sonuçlarını ortaya koymakla yetinelim. İnsanın doğal olan özgürlüğünü yitirip kulluğu-köleliği arzulayacak kadar kötü bir duruma düşmesi, ancak belli bir iktidar biçiminin, yani siyasal iktidarın (ya da La Boétie'nin gözüyle, devletin) ortaya çıkmasıyla gerçekleşir. Bölünmüş olan her toplum, bir başka deyişle insanların yönetenler ve yönetilenler şeklinde ikiye ayrıldığı her toplum, zorunlu olarak bir kulluk toplumudur. Böyle bir varsayımı benimseyen La Boétie için bölünmüş toplumlar arasında bir ayrım yapmak, siyasal rejim türlerinden herhangi birini benimsemek, bir kulluk biçimi yerine bir başkasını seçmek demektir. Bu nedenden dolayı, yazar, Söylev'in hemen başında rejim türleri üzerinde tartışmak istemediğini belirtir.

$\mathrm{Bu}$ bağlamda ister istemez siyasal iktidarn kökeni sorunu gündeme geliyor. Çünkü doğal özgürlüğü yadsıyıp böylesine büyük bir kötülüğü içinde barındıran siyasal yaplar, dünyanın hemen hemen her yanında g€rçekleşmiş durumda. Bir zoon politikon olmayan ınsan, "siyasallaşıp" siyasetin gerektirdiği bağımlılık ilişkileri içine girmiş. (Bu arada, La Boétie'nin insanı "siyasallaşan", bir başka deyişle siyasal iktidarı oluşturup ona boyun eğen tek hayvan olarak alglladığnı belirtelim.) Öyleyse, bu kötülüğün kaynağı nedir? Artık her yerde kolayca gözlemlenen bu olgu nasıl açıklanabilir? La Boétie, yapıtının ilk sayfalarında insan yaşamındaki bu değişimi bir kaza olarak nitelendirir, fakat, bu kazanın nasıl olduğu, devletin neden ortaya çıktığı sorununu yanıtlamaz. Clastres'ın da belirttiği gibi, (doğa ile aklı özdeşleştiren anlayıştan dolayı) böyle bir

tonio GRAMSCl'nin marksist düşünceye getirdiği "Devlet=hegemonya+diktatorya" tanımlaması ve buradan hareketle Louis ALTHUSSER ile Nicos POULANTZAS'ın geliçtirdikleri "devlet baskı aygıtları" ile "devlet ideolojik aygıtları" kavramları, kurumsallaşmıs siyasal iktidarın bu iki yönüne dikkati çekmektedirler. Bununle birlikte, Poulantzas, son dönem yapitlarında, devlet alanının bu iki kavramla belirlenmesinin yeterli olmadiğın ve bunun ancak betimsel bir değeri bulunduğunu vurgulamıştır. Daha geniş bilgi için bkz.: POULANTZAS, l'Etat, le pouvoir, le socialisme, Paris, PUF, 1878.

20 P. CLASTRES, "Liberté, Malencontre, Innommable", 'n La BOÉTtE, Discours.... op. cit., s. 238 . 
açıklamaya kalkışmak irrasyonelin (akıl-dışı olanın) nedenini aramak anlamına gelecektir. ${ }^{21}$ Akıl dışı olan, akıl yoluyla açıklanabilir mi?

Bununla birlikte, yine de La Boétie bu konuya bir açılklk getirmek istercesine elindeki tarihsel örneklerden hareket ederek bu kazayı iki ana etkene bağlar: Kuvvet ve hile, yani bazı insanların şiddet ya da kurnazlık yoluyla diğerleri üzerinde "egemenlik" kurmalar. ${ }^{22}$ Bu iki yolla siyasal iktidarın ilk evresi olarak şematik bir biçimde tanımlayabileceğimiz hükmetme-boyun eğme ilişkilerinin ortaya çıktığını ileri sürmek, hükmetme arzusunun daha önceden var olduğunu kabul etmek demektir. Oysa, özgürlüğün yitirilmesi kadar bu arzunun da belirmesi doğaya, dolayısıyla akla aykındır. Demek ki, La Boétie'nin bu açıklamaları devletin kökenine ilişkin değildir; çünkü siyasal iktidarın ilk aşaması için gereken hükmetme arzusunun, iktidar arzusunun nereden kaynaklandiğına değinilmemiş, yalnızca bu arzunun amacına ulaşmak için hangi yollara başvurduğu belirtilmiştir. La Boétie'nin bu konuyla ilgili olarak "kuvvet ve hile" dışında bir başka açıłklaması daha var ki, aslında hiçbir şey açıklamaz. Bu üçüncü yol, halkın hiçbir neden, hiçbir zorlama olmadan durup dururken kendini kul-köle kllması, bir başka deyişle kendini boyunduruk altina sokacak siyasal iktidar kurumunu yaratmasıdır. Burada da devletin neden belirdiğini göremiyoruz; zaten La Boétie'nin dediği gibi hiçbir neden yoktur. Clastres'ın saptamasından hareket edildiğinde, Söylev'de devletsiz toplumdan devletli topluma, ya da bir başka açıdan bakuldığında rasyonel bir yaşamdan irrasyonel bir yaşama geçiş anını belirleyen bu kazanın nedenini açıklamaya yönelik hiçbir şeyin bulunamayacağı, çünkü yazarın gözünde bu olgunun bir çeşit "kollektif delilikten" başka bir şey olamayacağı sonucuna ulaşılır (Hiç kuşkusuz, bir 16. yüzyıl düşünürü olan La Boétie'den bu sorunu derinleştirip siyaset psikolojisi yapmasını beklemek ise boşuna olurdu).

Söylev, o dönemde bilinen tarihi aşarak devletin insanllk için bir yazgı olmadığını ortaya koyar. La Boétie, devleti doğal olmayan yapay bir kurum biçiminde algılamasıyla Machiavelli gibi, Hobbes gibi modern siyasal düşünürlere yaklaşır, ancak onlardan önemli bir noktada ayrilır. Ona göre devlet, toplumun varlığı için, toplumun kendisini sürdürmesi için zorunlu bir koşul (sine qua non) değildir. Bu bakımdan La Boétie'nin yapıtı, "toplum devletten bağımsız olarak düşünülemez" şeklindeki yerleşmiş kanıya açık bir başkaldırışı simgeler. Antropolojik bir yaklaşım içeren Söylev'de insan, ne Machiavelli'nin Hükümdar'ındaki gibi başka-

\footnotetext{
21 İbid.. s. 235.

${ }^{22}$ Buna benzer bir biçimde, MACHTẠVELl, Prens'ine hem aslan hem de tilki gibi davranarak yerine göre :jiddete ya da kurnazlığa (ya da her ikisine birden) başvurmasın salık verir.
} 
larının kuyusunu kazan "kötü" bir yaratık, ne de Hobbes'un Leviathan'daki (artık günümüzde klasikleşmiş) deyişiyle bir homo homini lupus'tur. ${ }^{23}$ La Boétie'nin gerçek bir felsefi natüralizm biçiminde beliren doğa anlayışı, insanı hemcinsleriyle barış içinde yaşayabilmesi için herhangi bir dış ya da yapay güce gereksinim duymayan bir yaratık olarak ortaya koyar: "Tanrı'nın vekili ve insanların yöneticisi olan Doğa" (s. 254), insanları akılsal (ussal) yetilerle bezendirmenin dışında, onları aynı biçimde yaratarak birbirlerini tanımalarını sağlar. Dahası, var olan doğal eşitsizlikler, toplumsal eşitsizlikleri yaratacak bir tramplen işlevi görmek şöyle dursun, tam tersine insanlar arasındaki sevginin, dayanışmanın daha da güçlenmesine neden olurlar. Demek ki, özgürlüğün doğal olması, insanların kendilerini başkalarında görebilmelerinden, birbirlerini "yoldaş olarak ya da daha doğrusu kardeş olarak" (s: 254) taniyabilmelerinden kaynaklanmaktadır. Karşlıklı birbirini tanıma fenomeni ve bunun sonucu olarak beliren consensus olgusu ise, insanların konuşma yeteneği sayesinde gerçekleşmekı dir.

La Boétie, "Doğa'nın...herkesi birleştirmekten çok birler yapmayı istediğini" (s. 254) yazar. Claude Lefort'a göre böyle bir görüşü (yani insanların doğal konumlarının, birleşip bir bütün oluşturmą değil,' fakat herkesin "bir"ler biçiminde varlıklarını sürdürmek olduğu görüşünü) ileri sürmek, toplumsal ilişkileri bireylerin karşılıklı iletişim ve anlaşmalarına bağlamak, bireyler arasındaki farklılığı ilke olarak kabullenmek ve bu farklılı̆ğn gerçek yaşama yansımadığını söylemek demektir. ${ }^{24}$ Uyumlu (ve özgür) bir toplum, insanlarn bir bütün içinde eritilmesiyle kurulamaz; bu, herkesin kendi kişiliğini koruyup sürdürebildiği bir ortamı gerektirmektedir. Böylece Söylev'de, uyrukların ya da yurttaşların "bir"liğini, iyi bir toplumun belirtisi olarak gösteren siyasal yöneticilerin yalanı açığa vurulmuş olmaktadır. ${ }^{25}$

La Boétie'ye göre iyi toplum, doğaya, akla uygun olarak yönetenleryönetilenler farklılaşmasının oluşmadığı ve insanların siyasal iktidarca

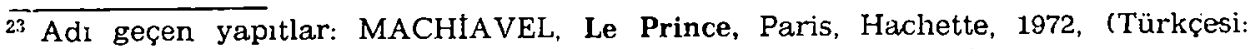
Hükümdar, Ist., Sosyal Y., 1984); HOBBES, Léviathan, Paris, Sirey, 1971.

24 Farklılaşma toplumda bölünmeyi, parçalanmayı yaratır. Oysa buradaki farklılık,- bir bakıma moral kişilik düzeyinde bulunmaktadır ve herkesin birbirine benzeyen birler olması, La Bośtie'nin deyişiyle toplumun daha sıkı bağlarla bağlanmasını sağlamaktadır. Aynı zamanda, özgürlüğün ve dostluğun sürmesinin ancak "bir"in çoğul olmasıyla olası kılındığını belirten La Boétie, daha ileride göreceğimiz üzere tiranı yani egemeni (ve de bu kişide somutlaşan devlet egemenliğini) - tekil anlamda- "bir" olarak algılayarak bu kişinin, bu kurumun insanlara yabancı oluşunu, insan doğasına özgü hiç bir şey taşımadığını dile getirir. Bu bağlamda Söylev'in ilk zamanlarda Contr'un (Bire karşı) başlığı altında yayımlanmış olduğunu da gözden kaçırmamak gerekir.

2:5 Claude LEFORT, "Le Nom d'Un", in La BOÉTtE, Discours..., op. cit., s. 271. 
bir koyun sürüsü konumuna indirgenmediği bir toplumdur. Eğer sözleşmeci düsünürlerin terminolojisine baş vurulursa, bu toplum modelinin "doğa durumu"nu karşıladuğı söylenebilir. ${ }^{26} \mathrm{Bu}$ yakıştırmadan hareket edildiğinde Söylev'deki doğa durumu anlayışının daha çok Locke'takini andırdığı görülmektedir; çïnkü her ikisi de, genelde rasyonel, barışcıl, uyumlu olarak tanımianmıstrr. La Boétie, doğa durumundan (yani doğal toplumdan) toplum dvrumuna (yani devletli topluma) geçişi açıklamaya kalkışmamakla Locke'un çelişkilerine düşmekten kurtulmuştur. Yoksa o da tıpkı Locke giti, bu ilk durumun yine de belli ölçülerde irrasyonalizmi, savaşı barındırdığını ya da Rousseau gibi özgürlüğü sınırlayan, hatta yok eden bölïnmenin, yapay eşitsizliklerin bu ilk durumda ortaya çıktıklarını kabul eimek zorunda kalacaktı.

Bölünme, toplumun ontolojik bir yapısı değildir. ${ }^{27}$ La Boétie Rousseau'dan farklı olarak, bölünmenin olmadığı bir toplumun belki de hiçbir zaman var olmadığını söylemez. ${ }^{28}$ Insanlar yozlaşmaları sonucu böyle bir

${ }^{28}$ Doğa durumu kavramının 'oplumsal bir yaşamı dişladığı' samılmasın. Gerçekte bu kavram, gerek Hobbes'ta gerekse Locke'ta ve hatta Rousseau'da egemensiz toplum durumunu ifade eder. Daha geniş bilgi için bkz: MACPHERSON, La théorie politique de l'individualisme possessif de Hobbes à Locke, Paris, Gallimard, 1971.

${ }^{27}$ La Boétie'nin açıkça vurgulımamıs olmakla birlikte, devietin ortaya çıkışında ekonomik yapının yeri üzerindeki güncelliğini bir türlü yitirmeyen ve kesin bir sonuca ulaşılamayan tartısmanın taraflarından birinin görüşünü dolaylı bir biçimde de olsa yansıttığı görülmektedir. La Bośtie'ye göre bölünme ancak siyasal iktidarın bulunduğu toplumda olduğuna göre, toplumsal (ve özellikle ekonomik) eşitsizliklerin belirnesi için zorunlu olarak devletin ortaya çımması gerekiyor demektir. Yani belirleyici olan siyasal yapıdır, ekonomik alanı biçimlendiren devlettir. Bir zamichlar marksizme bulaşmıs ve şimdilerde marksizmin dışladığı "gerçekleri" bulu’̣ gün ışığına çıkarmaya uğraşan CLASTRES ile LEFORT'un La Boétie'ye ilgri duymalarınn nedenlerinden biri Söylev'in böyle bir savı içermesidir.

ĊLASTRES, Le Société contro l'Etat adl yapıtında (op. cit., s. 169-175) marksizme keskin eleştiriler yöneltir: "Demek ki belirleyici olan siyasal kopmadır, yoksa ekonomik değişim değil... Siiyasal iktidar ilişkisi ekonomik sömürü ilişsisinden önce vardır ve onu oluşturur. Yabancllaşma, ekonomik olmadan önce siyasaldır, iktidar emekten öncedir, ekonomik olan siyasal olandan kaynaklanir, devletin ortaya çıkış sınffların belirmesini belirler." CLASTRES'a göre, eğer toplum ezenler-ezilenler biçiminde düzenlenmişse, bu düzenin varlığının koşulu olarak bir güç uygulanmasının yaní devletin özünü oluşturan "meşru şiddet kullanma tekelinin" bulunduğu kabul edilmelidir. Oyleyse devlete ne gerek vardır? Nasıl olsa, devletin özü, yani şiddet, toplumun bölünmesine içkindir ve devletin gör'düğü işlev o olmasa da yerine getirilmektedir. CLASTRES, bu kanıtlamasıyla devleti bir baskı aracı olarak gören marksist anlayışı yadsıdığını ileri sürer.

28 Hobbes için de doğa durumu tarihsel bir gerçek değil, fakat kuramu için gereken lojik bir varsayumder. 
toplumu artık anımsamasalar bile, bu toplum bir zamanlar var olmustur, dahası belki dünyanın bazı yörelerinde halâ varlığını sürdürebilmektedir. Clastres, La Boétie'de görülen bu a priori (peşin hükümlü) devletsiz toplum düşüncesinin yalnızca tümdengelimsel bir çıkarsama olmayıp, 16. yüzyıl başlarında yeni dünya üzerinde yazılanlardan, kulaktan kulağa yayılan bilgilerden kaynaklanmış olabileceğini belirtir. ${ }^{29} \mathrm{La}$ Boétie, yeni dünyanın inançsız, kralsız, yasasız insanlarına ilgi duymuş ve onlarda "özgür doğal insan" modelini bulmuş olabilir. Savina bir kanıt getirmek isteyen Clastres, Söylev'deki bir bölümün yeni bulunmuş bu toplumlara ve buraların insanlarına çok açık bir atıf oluşturduğunu ileri sürer. ${ }^{30} \mathrm{Her}$ ne kadar Clastres'ın bu savı bir kesinlik taşımıyorsa da, La Boétie'nin çeşitli zaman ve mekanlarda var olduğundan kuşkulanmadığı ve toplumsal uyumun bir siyasal iktidar durumuna gereksinim duyulmadan kendiliğinden gerçekleştiği böyle bir topluma özlem duymuş olduğu bir gerçek.

Fakat Söylev, bir "ideal" toplum ütopyası çizmeye yönelmez. Bir militan olmayan La Boétie bunu, gerçekleştirilecek ya da en azından Thomas More'un deyişiyle gerçekleşmesinin" bir umuttan çok bir dilek" 31 olduğu toplumsal ,(ve siyasal) bir proje biçiminde sunmaz. Nedeni, söylevinin başında doğrudan doğruya hitap ettiği ve özgürlük için eylem çağrnsında bulunabileceği halktan umudunu kesmiş görünmesidir. İlk bakışta, yazarın böyle bir tutum takınmasıyla bir çelişki içine düştügü sanılabilir. Çünkü kitabın ilk sayfalarında yitirilmiş özgür yaşama yeniden kavuşmanın hiç de zor olmadığı belirtilir: "Tirana karşı koymak, onunla savaşmak gerekmez bile. Ülke ona kulluk etmemeye karar versin bir kere, tiran kendiliğinden yok olup gider." (s. 251). Ancak daha sonra bu kurtulus

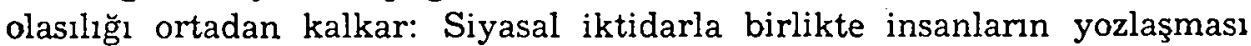
öylesine büyük boyutlara ulaşır ki, halktan bunu başarmasını beklemek bile boşuna olur artık. La Boétie'nin deyişiyle halkın içine düştügü hastalık, yani bu gönüllü kulluk durumu öldürücüdür, iyileşme umudu hiç yoktur.

Bununla birlikte siyasal kulluk, bir edilgenlik durumu olarak alg1lanmamalıdır. Halk ayaklanır ve bir bakıma sürekli ayaklanmaktadır. La Boétie, 1548 yılındaki büyük köylü ayaklanmasını görmüş, hatta büyük

23 Pierre CLASTRES, "Liberté, Malencontre, Innommable", op. cit., s. 244.

${ }^{30}$ Clastres'in sözünü ettiği Söylev'deki bölüm şudur: "Fakat, eğer bugün ne bağımulığa alışkın ne de özgürlüğe tutkun yepyeni insanlar doğsa, bu insanlar bağımlılığın ve özgürlüğün ne olduğunu bilmedikleri gibi adlannı da hiç duymamıs olsalardı veya uyruk olma ya da özgür yaşama seçeneği ile karşı harsıya kalsalardı, hangisini kabul ederlerdi? Bir insana hizmet etmeyi değil de yalnuzca akla boyun eğmeyi sevecekleri üzerinde kuşkuya düşmemek gerek." (s. 257).

31 Thomas MORE, Utopia, Istanbul, Cem Yaynevi, 1981, s. 128. 
bir olasılıkla bunu yaşamıştır. Ancak La Boétie'nin gözünde, bu ve bunun gibi ayaklanmalar özgürlüğü doğuracak gerçek bir kopuş hareketi niteliği taşımazlar ve devleti yok etmeyi amaçlayan radikal bir değişim anlayışından yoksundurlar. Bunlar olsa olsa, kurulu siyasal düzen içinde kulluğun, köleliğin biraz daha "şekerlendirilip tatlandırılması" (s. 265) isteminde bulunan eylemlerden başka bir şey değillerdir. Üstelik, var olan iktidar yıkıp onun yerine insancıl, yumuşak bir siyasal rejim getirmeye yönelik bir ayaklanmanın diğgerlerinden hiçbir farkı yoktur, hatta gerçekleşirse çok daha kötü sonuçlar doğurur. Tıpkı Sezar'ın "kulluğu tatlılaştıran zehirli yumuşaklığı" (s. 265) gibi paternalist ve popülist bir görünüm gösteren iktidarlar döneminde, insanların kulluğu sevip onu tüm benlikleriyle benimsemeleri çok kolay olur ve böylece hiç olmazsa bazı insanlarda yaşatılabilen küçük özgürlük ışı̆̆ı da eriyip söner.

Bu bağlamda La Boétie'nin kötümser bir düşünür olduğu ileri sürülebilir. Gerçek kopuşun ancak insanların kulluk psikolojisinden kurtulmalarına bağlı olduğu anlaşıllyor. Oysa bu da olanaksız görünüyor, çünkü bu psikolojiyi sürekli yeniden üreten, insanları köleliğe koşullandıran mekanizmayı sürekli bir biçimde işleten, devletin ta kendisidir (ya da Louis Althusser'in deyişiyle devletin ideolojik aygitlarıdir). Siyasal iktidarin kurumsallaşmasıyla birlikte, devletin kendisini sürdürmek için gerekli olan (devletin gerekliliği üzerindeki) ideolojik söylem de beliriverir. Böylece bir kısır döngü içine girilmiş olunur: Devletten kurtulmak için bu psikolojiyi yıkmak gerek, bu psikolojiyi yıkmak ise ancak devleti ortadan kaldırmakla mümkün! Işte La Boétie'nin umutsuzluğa yönelmesinin ardında yatan uslama bu. Bu nedenle yapıtını militan bir perspektif içinde kaleme almayan La Boétie, ne halk ayaklanmalarının sözcüsü ne de. "16. yüzyıl köylülerinin Marx'ı olmuştur." 32

Demek ki Söylev, militanca okunmaya kalkışllınca kötümserlik damgasinı da yer. Oysa, bu konuya "devletli toplum-devletsiz toplum" kavramları kategorisi içinde yaklaşıldığında, La Boétie'nin döneminin bilgi birikiminin yetersizliğinden dolayı tam bir bilince ulaşamamıs olmakla birlikte, belli bir "gerçeği" dile getirdiği görülüyor. Onun "Halk bir kere kulluklaşmaya görsün, özgürlüğü öylesine unutuyor ki, artık onun uyanıp yeniden özgürlügünü ele geçirmesi olanaksız oluyor" (s. 257) yargısı, pek açık bir biçimde olmasa da, günümüzde bazı antropolog ve etnologların görüş birliğine vardığı bir görgül saptamayı formüle etmektedir: Geçiş yalnızca devletsiz toplumdan devletli topluma doğru olur, bunun tersi hiçbir zaman gerçekleşmemiştir. ${ }^{33}$ Iktidar arzusuyla kulluk istencinin bir kez ortaya çıktılar mı artık yok olamayacakları görüşünden hareket eden Lá

32 ABENSOUR M. ve GAUCHET M., op. cit., s. XXI. 
Boétie, kitlesel bir eylem çağrısında bulunmanın hiçbir sonuç, vermeyeceğini kavrayıp böyle bị işe kalkışmamıştır. ${ }^{34}$

Söylev, siyasal iktidarın kökeni sorununu yanıtsız bırakıp bunun özünü belirledikten sonra içerdiği başat konuya yönelir. Görüldüğü gibi kulluk istenci, boyun eğme arzusu, doğuştan değil, fakat sonradan olmadır. $\mathrm{Bu}$ arzu, çok büyük bir etkinliğe sảhip bulunmakta ve insanların kendilerini ondan kurtarıp yeniden özgürlüğe, yani kurumsallaşmış siyasal iktidarı dişlayan topluma dönmeleri hemen hemen olanaksız görünmektedir. Bu bakımdan siyaseti anlamak, siyaset üzerinde düşünmek, gönüllü kulluğun nassl oluşup nasıl sürdüğünün açıklanması olmaktadır. İşte La Boétie, Söylev'de bu sorunların yanıtlanmasına ağırlık verir.

\section{HEGEMONYA}

Söylev'de, tek bir kişinin, "bir"in milyonlarca insana hükmetmesi, adlandırılamayacak kadar doğaya aykırı bir olgu ve boyun eğenler açısından büyük bir erdemsizlik olarak gösteriliyor .La Boétie, ilk önce, bu durumun inșanlığın korkaklığından, alçaklığından kaynaklanıp kaynaklanmadığını belirlemeye çalışır. Yanıtı olumsuzdur: İki hatta on kişi tek bir insandan korkabilir, fakat milyonlarmn sırf korktuklarindan dolay kulluğu-köleliği benimsemeleri düşünülemez. Korkaklığın da belli bir sinırı vardır ve böylesine. büyük boyutlara ulaşması olanaksızdır. Üstelik, tiranın her türlü kararına ve uygulamasına ses çıkarmadan katlanan insan, savaşmak söz konusu olduğunda canını vermeye varacak kadar büyük bir yüreklilik gösteren insanın ta kendisidir. ${ }^{35}$ Neden, korkaklık olmadiğına göre acaba insanların zenginlik elde etme arzusunda bulunabilir mi? En açık ifadesini Locke’te bulmuş olan tam bir güvence ve rahatlık içinde mal-mülk edinme uğruna doğal özgürlükten vazgeçip bir siyasal iktidara bağlanma görüşü, pek de yabana atılacak gibi değil. Fakat

33 CLASTRES, LAPIERRE gibi düşünürlerin savundukları bu görüş, marksizmdeki devletsiz toplum aşamasının bir düş olarak algılanması gerektiğini vurgular.

34 La Boétie'nin devletli toplumdan devletsiz topluma geçilemeyeceğini benimsemesi, onun bazı yorumcular tarafından bir anarşist ya da en azınden aniarşist akımın bir öncüsü olarak değerlendirilmesindeki yanılgıyı ortaya koyar. LANDAUER'in Söylev hakkındaki şu sözleri bu yorumların tipik bir örneğidir: "Bu deneme, daha sonraları ve başka dillerde Godwin ve Stirner'în, Proudhon, Bakunin ve Tolstoy'un söyleyeceklerini dile getirmektedir: Insanlar iktidara bağmlı değil, fakat birbirlerine kardeş olarak bağlı olmalıdırlar. tktidar olmadan: An-arke". Gustav LANDAUER, "Extrait de Die Revolution", in LA BOETIE, Discours..., op. cit., s. 85.

35 La Boétie, tiranları için (dolayısıyla kul-köle durumların sürdürmek için). seve seve canlarını veren insanlara örnek olarak Osmanlı Padişahı'nın "kullarını" gösterir. 
La Boétie, bu ekonomik açıklamayı da reddeder: "Sizler gözünüzün önünde, en güzel ve en parlak kazançlarınızın götürülüşüne, tarlalarınızın yağmalanmasına, evlerinizin ve eşyalarınızın çalınmasına seyirci kalıyorsunuz. Öyle bir yaşam sürüyorsunuz ki, hiçbir şeyin size ait olduğunu söyleyebilecek durumda değilsiniz" (s. 252-253). Yalnız halk değil, fakat devlet mekanizmasının çeşitli basamaklarında bulunup siyasal iktidar sahibine hizmet eden kişiler de can ve mal güvenliğinden yoksundurlar.

Düşünülemeyecek kadar mantık dişı görünen gönüllü kulluk olgusunu var kılan, insan doğasının yozlaşmasıdır ya da daha doğrusu insanın yozlaşarak bir ikinci dogaya sahip olmasıdır. Clastres'a göre La Boétie, modern insanın, bölünmüş toplum insanının antropolojisini kuran ilk kişidir ve üç yüzyıl öncesinden Marx'ınkinden çok Nietzsche'nin yozlaşmayla yabanclaşmaya ilişkin çalışmalarına $1 s ̧$ lk tutmuş olan düşünürdür. ${ }^{36}$ Evet, özgür olma, özgürlüğü sevip kollama doğaldır, ancak özgürlügün bu niteliği onun sürgit olacağı anlamına gelmez; çünkü "doğal olan ne kadar iyi olursa olsun, ę̆ger onun bakımı yapılmazsa yok olup gider." (s. 258) La Boétie'nin görenekler, alışkanlıklar ya da eğitim diye adlandırdığı kültürel ve ideolojik yapı, insanlar üzerinde büyük bir etkiye sahiptir ve özgürlüğ̈̈ yadsıyan bir biçim aldığında insanların birinci doğalarnn yitirmelerine neden olur.

Bu durumda ortaya çıkan sorun, doğasını yitiren insanın hâlâ insan olma niteliğini koruyup koruyamadığıdır. İlk bakışta, insanın özgür bir varlık olmamayı yeğleyerek insan olmamayı seçtiği sanılabilir. Oysa, burada insanın yeni bir tanımlanmasıyla karşılaşılıyor. Doğasını yitirmiş olmakla birlikte insan, bir bakıma hâlâ özgürdür; çünkü bu kez yozlaşmayı, yabancılaşmayı seçmiştir, seçimi yapan yine kendisidir. Öyle görülüyor ki, "özgürlük öylesine büyük ve öylesine hos bir iyiliktir ki, bir kez kayboldu mu tüm kötülükler arka arkaya sıralanırlar" (s. 252) diyen La Boétie için yabancılaşma, ilk önce siyasaldır, ekonomik yabancılaşma bunun ardından gelir. Doğasının bozulması sonucunda insanın istenci de anlam değiştirir, özgürlük yerine kulluğu amaçlar. Bunun yanında, kulluk etme alışkanlığı insanda bir çeşit özgürlük biçimi alır. Böylece insan, iki ayr (ve karşıt) doğaya sahip olabilen tek yaratık olarak belirir. "Eğitim ve alışkanlıkla kazanılmış her şey doğal olduğuna" (s. 260) göre, siyasal iktidar ortaya çıkar çıłmaz birinci insan doğası yerini ikinci insan doğasına bırakır ve yeni insan, yani yozlaşıp yabancılaşmış insan gerçekleşmiş olur. İnsan doğasından yola çlkmış olan Hobbes, yüz yıl sonra buna benzer bir görüşü siyasal kuramını temellendirmede kullanmıştır. ${ }^{37}$

s6 Pierre CLASTRES, "Liberté, Malencontre, Innommable", op. cit., s. 236.

${ }^{37}$ Thomas HOBBES'a göre doğa durumundan' toplum durumuna geçilirken insan da değişir, daha doğrusu bu geçişin olabilmesi için ilk önce insan kendi doğasını 
Fakat Hobbes, La Boétie'den farklı olarak, ikinci doğanın insana özgü gerçek doğa olduğunu, siyasal bölünmenin rasyonel bir varlık olan insanın özgür iradesinden kaynaklandığını ve Hegel'den önce "gerçek özgürlügün" ancak siyasal iktidar kurumuna (Leviathan'a) bağımlı olmakla gerçekleşebileceğini ileri sürmüştür. Oysa, Söylev'de kulluk doğası, her ne kadar insan tarafından bir çeşit özgürlük biçiminde algllanmış olsa da, gerçek bir özgür seçimin sonucu değildir; daha önceden belirmiş olan siyasal iktidar, kişileri çeşitli yöntemlerle yozlaşmaya, bir başka deyişle kulluğu arzulayıp seçmeye koşullandırmıştır.

İktidarn en çıplak görünümü baskıdır, şiddettir. La Boétie'ye göre insanlar arasında dostluk, kardeşlik bağlamnı kuran dil, iktidar karşısında bu olguyu adlandıramayacak kadar aciz kalmaktadır. Hükmetme ile iktidara rıza göstererek boyun eğme ilişkilerinin bir adla tanımlanamamalarının nedeni, siyasetin dil (konuşma) olmadan iletişimi sağlamıs olmasıdır; bir başka deyişle dil dostluksa, siyaset şiddettir. Fakat siyasal iktidarın tam anlamıyla gerçekleşmesi, hele gönüllü kulluğun oluşması için yalnızca şiddet yeterli olmaz; kuvvet zoruyla, kılı̧̧ zoruyla insanların köle yapılmalarına karşın onların bu kölelik durumların benimseyip sevmelerini sağlamak olanaksızdır. Rousseau'nun "en güçlü gücünü hak, boyun eğmeyi de ödev biçimine sokmadıkça hep egemen kalacak kadar güçlü değildir"38 deyişiyle açıkça belirttiği üzere yönetilenlerin gözünde belli bir meşruluk kazanamayan hiçbir siyasal iktidar, varlığını uzun bir süre sürdürmek başarısını gösteremez. Meşruluk, iktidarı elinde bulunduran kişinin (ya da kişilerin) ne istencine ne de gücüne bağımlı olmadığından dolayı yeri doldurulamaz bir öneme sahiptir. İktidara dışarıdan gelir ve iktidarın daha sağlam temeller üzerine oturmasını sağlar. Onamayı (rıza göstermeyi) yücelten meşruluk, korkudan kaynaklanan davranışları çeşitli ödevlerden doğan yükümlülükler biçimine dönüştürür. ${ }^{39}$ Meşruluğu elde eden iktidar ise, kendini çepeçevre saran bir imgeler, inançlar sistemi yaratarak kişilerin iktidar ilişkilerini kendisinin saptadığı yönde algılanmalarnna yol açar.

değiştirir; fakat bu bir yozlaşma değil. tam tersine gerçek insanın ortaya çıkışidır.

Bununla ilgili olarak sözü bir HOBBES uzmanına bırakalım: "Doğru önermelerle desteklenmiş ve sözcüklerin söylem seklinde birleşmelerinden oluşmuş rasyonel teleolojik hesap, insanın kendi kendisini yaratmasına yarayan aracı oluşturur. Böylece insan, bu teleolojik hesap, konuşma ve geleceği algılamayla hareket ederek toplumsal insanın -yani gerçek insanın- yapıcısı, artisti işlevini yerine getirir." Raymond POLIN, Politique et Philosophie chez Thomas Hobbes, Paris, Vrin, 1977, s. 13.

38 Jean-Jacques ROUSSEAU, Toplum Sözleşmesi, Istanbul, Adam Y., 1982, s. 17.

${ }^{29}$ Georges BURDEAU, l'Etat, Paris, Seuil, 1970, s. 45. 
Gönüllü kulluğun gizinin burada yattığını belirten La Boétie; Rousseau'dan daha ileri gider: İnsanların köle kalmalarının nedeni korkaklıkları olmadığından başka, ${ }^{40}$ onların boyun eğmeyi bir ödev gibi görmeleri de yeterli değildir. İktidarın kendini tam bir güvence altına sokabilmesi için yönetilenlerin boyun eğmeyi bir ödev gibi algilamaları dişında, verilen kararlarla bu kararlarm uygulanmasinı onaylamalar ve iktidardan kaynaklanan her şeyi (dolayısıyla kul-köle olmalarını) sevip süräürmek istemeleri gerekir.

Söylev'de ele alınan siyasal iktidar, yetke (otorite) niteliğine bürünmüş olan iktidardır. Bourricaud'nun tanımıla "yetke, meşru iktidardır ya da daha açık bir biçimde kaba çıplak bir güç gibi değil, fakat haklı olduğundan ya da hiç olmazsa haklı olabileceğinden dolayı insanların güven duyabildiği bir güç şeklinde algılanan buyurmadır."'1 La Boétie'nin bir aydın olarak her tür siyasal rejime karşı çıkması, var olan gerçeği, iktidar gerçeğini değiştirmez. Bu bakımdan La Boétie, neyin olup neyin olmaması biçiminde ideal toplum anlayışıla ilgili spekülasyonlara girmeyip karşısındaki gerçeği anlamaya çalışır ve (açıkça bu kavramlari kullanmamış olmakla birlikte) siyasal iktidarın yetkeye dönüşerek kendini, bir başka deyişle özünü, haklı ve meşru göstermeyi başarmış olduğunu vurgular. Zaten böyle olmasaydı, siyasal iktidar yerleşemezdi; gücünü buyurma-onama ilişkileriyle pekiştirmeden yalnızca hükmetme-boyun eğme ilişkilerine dayanarak varlığını sürdürmesi olanaksız olurdu.

Siyasal iktidar varsa, insanların onu isteyip onadığı için vardır. Bundan dolayı siyasal iktidarın varlığı, prensin, yönetenin değil, halkın istencine (volontarizm'ine) bağhdır. Mesnard, La Boétie ile Machiavelli'nin görüşlerinin karşıt yönlere doğru gelişmekle birlikte aynı ilkeden kaynaklandıklarını belirtir: "Gerek Machiavelli, gerek La Boétie için yetke ancak uyrukların kabul etmesiyle kurulur. Fakat ilki prense uyruklarının rızasını zorla elde edebileceğini öğretirken, diğeri halka reddetmesinin ne denli güçlü bir şey olduğunu gösterir." ${ }^{22}$ Gerçekten La Boétie'ye göre, siyasal iktidarın yıkılması için halkın ayaklanıp mücadeleye girmesi gerekmez bile, onu desteklememesi, bir başka deyişle pasif direnişe geçmesi yeterli olur. Bu bağlamda, La Boétie'yi Fransız Devrimi'ne kadar halkın böylesine karşı konmaz bir güce sahip olduğunu açlklayan tek düşünür

\footnotetext{
40 "Ilk köleleri köle yapan kaba güçse, onları kölelikte tutan korkaklıklar olmuştur". J.J. ROUSSEAU, Toplum Sözleşmesi, op. cit., s. 16.

${ }^{41}$ François BOURRICAUD, Esquisse d’une théorie de l'autorité, Paris, Plon, 1969, S. 10.

42 Flerre MESNARD, L'Essor de la philosophie politique au XVIe Siècle, Paris, Vrin, 1977. 2. Basım, s. 400 .
} 
olarak yorumlamak mümkün. ${ }^{43}$ Ancak Söylev'in bütünü göz önüne alındığında, bu açıklamanın halkın gücünü değil, fakat güçsüzlüğünü vurguladığı görülür. Çünkü siyasal iktidar bir kere kurulup yerleşti mi, halk bu büyük gücünü psikolojik olarak tümüyle yitirir. Bu durumda bulunan halk, artık doğası yozlaşmıs, köleliği benimsemiş olan halktır. Derinliklerinde yatan bu gücün bilincine varamayacak kadar yozlaşmanın içine düşen halktan La Boétie'nin bir beklentisi yoktur ve ondan tiksinircesine "aşağı halk tabakası" diye söz etmekten de çekinmez.

Bununla birlikte La Boétie, bu insanlara bütünüyle olumsuz bir biçimde yaklaşmaz: "Boyunduruk altında doğup da özgürlüğün gölgesini bile göremeyip köle olmanın ne kadar kötü bir şey olduğunu anlayamayan insanların hoş görülmelerinin ya da bağışlanmalarının" (s. 260) gerektiğini belirtirken, gönüllü kulluğun yerleşmesinde iktidarın oynadığ? role dikkati çeker. Çünkü insanların, içinde bulundukları durumu doğal karşılayıp benimsemeleri için onlara belli değer ve davranış kalıplam, belli bir dünya görüşü aşılamak gerekir. Bu ideolojik işlevi yerine getiren de siyasal iktidardır. La Boétie, tıpkı Platon gibi, ${ }^{44}$ ideolojik koşullandırmanın ancak istenilen kalıba sokulabilecek ikinci kuşak üzerinde etkili olabileceğini de ekler: “... Bundan sonra gelen kuşak, özgürlüğü hiç görmeyip tanımadığından dolayı, pişmanlık duymadan hizmet eder ve ondan öncekilerin zorla yaptıklarını seve seve yerine getirir. Boyunduruk altında doğan insanlar, kulluk, kölelik içinde büyütülüp eğitilirler." (s. 257). Dolayısıyla bu insanlar, siyasal iktidarı yıkmaya yönelik herhangi bir eyleme kalkişamazlar. Böyle bir eylemin gerektirdiği özgür düşünceden, özgür iradeden yoksundurlar; kurulu düzeni sevip benimsemekte ve sürdürdükleri yaşamın dişında başka yaşam biçimleri olduğunun ya da olabileceğinin bile farkına varamamaktadırlar.

$\mathrm{Bu}$ sonucu yaratan ideolojik söylemdir (dolayısıyla ideolojik söyle-

${ }^{43}$ François HINCKER, "Introduction" in CEuvres Politiques de la Boétie, op. cit., s. 29.

14 Platon ideal devletlerinin modelini oluşturduğu iki yapıtında kurulacak yeni düzenin, kendi deyişiyle "balmumu gibi biçimlendirilebilecek" IYasalar, VII, 789 e) çocukların ya da ikinci kuşağın benimsemesiyle gerçekleşebileceğini açıklar: "(Filozoflar) devletimizde on yll dolduranlarnn hepsini kurda yaşamaya gönderecekler, çocukları alıp zamanın ve ana babanın göreneklerinden koruyacaklaı: Onlarn kendi görgülerine, yukarıda anlattığımız kendi ilkelerine göre yetiştirecekler." (Devlet, VII, 541a).

"Bu insanlar hiç bir yasamızı kendi istekleriyle kabul etmezler. Fakat, eğer onların çocuklamnın sindire sindire yapılmış ortak bir eğitim sonunda yasalarımızı anlayıp benimseyecekleri kadar beklersek... şahsen ben, bu dönem atlatıldıktan sonra, bu biçimde yönetilen devletin uzun ylllar süreceğinden en ufak bir kuşku duymuyorum." (Yasalar, VI, $752 \mathrm{c}$ ).

Platon'un bölümler aktardığımız iki yapıtı şunlardır: Devlet, Istanbul, Remzi K., 1980 ve Les Lois, Paris, Librairie Garnier Frères, 1946. 
min aldığı somut biçimlerdir, bunun pratikler bütünüdür). Bu bakımdan, dili yalnızca insanlar arasında dostluk ilişkileri kuran bir bağ olarak ele alan La Boétie'nin madalyonun diğer yüzünü farketmekle birlikte pek iyi kavrayamadığı anlaşılıyor. La Boétie, gönüllü kulluğun hakim ideolojinin beslediği göreneklerden, geleneklerden, eğitimden kaynaklandığını açıklamasına karşın, ideolojinin dil (konuşma) ile olan bağlantısını kuramaz. Konuşma, hem yakınlaştırıcı, hem parçalayıp bölücü iki karşıt işlevi birden yerine getirir; yalnız dostluğa değil, şiddete, tiranlığa da yol açabilir.

Söylev'e bakıldığında konuşmanın, insanların birbirlerini tanımasını sağlayıp aralannda dostluk ilişkileri oluşturan bir arą̧ biçiminde algılandığı görülüyor: "(Doğa) birbirimizle daha fazla yakınlaşıp kardeş̧e geçinmek, düşüncelerimizin ortak ve karşllkklı bildirisiyle istençlerimizin ortaklığını oluşturmak için hepimize birden bu büyük armağanı, ses ve konuşma armağanını vermiştir." (s. 254). Ancak bu ortaklık, bireylerin bir bütün içinde eriyip tek "Bir"in ortaya çıkması anlamına gelmez." $\mathrm{La}$ Boétie'ye göre insanlar "bir"lerdir, yani kişilik olarak birbirlerinden farklıdırlar ve özgürlük, bu farklılığın karşılıklı konuşma, karşılıklı söylem düzeyinde sürmesidir. Bir başka deyişle, "özgürlük, konuşmanın karşllkIl oluşunda bulunur; bu durum ise konuşmacıların farklılığını içerir."46 Demek ki Söylev'in mantığ 1 içinde "özgür toplum", çok sesli olan toplumdur, çok sesliliğin içinde birbirleriyle dostça bağlaşmıs ve "istençlerinin ortaklığını" sağlamış olan insanların toplumudur.

Madalyonun diğer yüzü ele alındığında, konuşmanın apayrı bir boyutuyla karşılaşılır. Buradaki konuşma, çok sesliliğini yitirip diyalogdan monologa dönüşmüs olmasından dolayı, kardeşliğin-dostluğun, dolayısıyla özgürlüğün yadsınmasi olarak belirir. Siyasal iktidarla birlikte, doğanın insanlığa "bu büyük armağanı" herkesin hakkı olmaktan çıkıp bir ayrıcalığa dönüşür. Clastres'ın deyişiyle "iktidarın her türlü elde edilişi, aynı zamanda bir söz (konuşma) kazancını da beraberinde getirir." Her iktidar, insanlar arasındaki ilişkilerin düzenlenmesine katkıda bulunan ve insanların kendi durumlarını onun yansıttı̆̆ı biçimde algılayıp yaşamalarını

${ }^{45}$ Çünkü daha önce de belirttiğimiz gibi, La Boétie bunu açıkça dile getirmiştir: "Doğa'nın tüm olanaklarla, bağlaşmamız ile toplumumuzun bağlannı daha sıkı bağlamaya uğraşmasından ve hepimizi birleştirmekten çok birler yapmayı her durumda göstermesinden dolayı, tüm insanların doğal olarak özgür olduğu üzerine kuşkuya düşmemek gerekir." (s. 254). Bu konuda Mesnard, ફ̧öyle bir yargıya varmaktadır: "Doğal olarak farklılaşmış bir yetkeye yol açan organizmacı sosyolojiye doğrudan doğruya karşı olan La Boétie, yalnızca, özerk (autonomel ve kesinlikle bağımsız insanlar arasında oluşan doğal bir toplumsallaşmayı tasarlar." (Op. cit., s. 394).

46 Brian SINGER. "The Politics of Obedience: The Discourse of Voluntary Servitude" in Telos, No. 43, Spring 1980, s. 224. 
sağlayan bu araç üzerinde elinden geldiğince bir tekel oluşturma amacını. güder. Singer, bu amacın Söylev'de sözü edilen tiranlık tarafından gerçekleştirildiğini belirtir: "Tiranlık, yalnız bir kişinin konuşup diğerlerinin onu dinlediği... ve kitlelerin tiranın söylevini tekrarlamaktan başka bir . şey yapmadığı bir durumu temsil eder." ${ }^{\text {47 }}$ Clastres, bu konuda siyasal rejimler arasında bir aymm gözetmek taraftar değildir; ona göre, ister prens, ister despot, ister devlet başkanı olsun her iktidar adamı, konuşmaya hükmetm€kle kalmayıp meşru konuşmanın tek kaynağını da oluşturur. ${ }^{48}$ Böylece tek merkezden yayılan sözler, (artık yitik) dostluk bağlamn değil, fakat toplumun (en azından yönetenler-yönetilenler biçimindeki) bölünmüşlügünü yansıtmaya başlar.

İktidarın kullandığı tek yönlü konuşma, birbirinden farklı çeşitli biçimler alabilir. İlk biçimiyle, tehditler vo korkutmalarla desteklenmiş bir buyurma olup dinleyenlerin itaatını sağlamaya yöneliktir; bu anlamda konuşma, iktidar olgusuna içkin olan şiddetin sözlü olarak dışarıya vurulmasından başka bir şey ifade etmez. Oysa daha önce de belirttiğimiz gibi, siyasal iktidarın kendini güvence altında sürdürebilmesi, uyruklarının ya da kullarının itaatını zor kullanarak sağlamasına bağlı değildir; bunun için halkın rızasının, onayının kazanılması gerekir. Yönetilenlerin ikna edilmesinde kullanılan araç yine konuşmadır; ancak bu kez buyurmaya kıyasla büyük bir içerik ve biçim değişimi geçiren konuşma, ideolojik söylem olarak karşımıza çıkar. ${ }^{49}$ Yeni oluşan siyasal iktidarın yaptiğı ilk işlerden biri, ideolojisini ortaya koyarak iktidarın doğallı̆̆ı, meşruluğu ya da gerekliliği üzerinde genel bir kanı yaratmak olur. Daha sonraki ideolojik evre, kurulu düzenin bireylerce benimsenip onaylanmasıdır. La Boétie bu durumu "göreneklerin... bize hizmet etmeyi ve kulluk zehirini yutup acı bulmamayı öğretmeleri" (s. 258) şeklinde dile getirir.

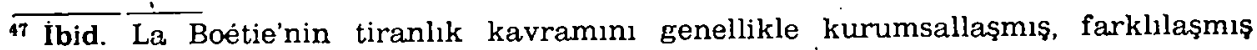
siyasal iktidar kavramı yerine kullandığı göz önüne alındığında, Singer'in bu tümceyle klasik anlamdaki tiranlığ $\mathrm{ml}$ yoksa tüm siyasal rejimleri mi tanımlamakta olduğu pek iyi anlaşılamamaktadır.

48 Clastres'in bu konudaki görüşleri için blkz: La société contre..., op. cit., s. 133-134.

- Siyasal iktidarnn elinde tuttuğu konuşma için "buyurma ve ideolojik söylem" şeklinde yaptığımız metodolojik ayrım, buyurmanın tümüyle ideolojinin dışında bulunduğu anlamına gelmez. Iktidarnn buyurma biçiminde beliren konuşması gonellikle ideolojik bir yüklem taşımaktadır. Buna karşılık ideolojik söylem de şiddetle yüklü olabilir. Bu konudaki çalışmalarıyla tanınan Fransız sosyologlam Bourdieu ile Passeron, yönetilen sınıflara belli düşünce ve davranış kalıplarının aşılanmasının temelinde sınıflar arasındaki güç ilişkilerinin yattığını belirtirler. Buradan hareketle. güç ilişkilerinin göz ardı edilerek kurulu düzenin meşru olarak benimsetilmesini, ya da bir başka deyişle yönetilenlerin üzerínde ideolojik egemenliğin kurulmasını "simgesel siddet" (violence symbolique) kavramıyla adlandirırlar. Daha geniş bilgi için bkz. Pierre BOURDIEU ve Jean-Claude PASSERON, La Reproduction, Paris, Minuit, 1970. 
Kişi, ideolojik söylemin içerdiği imgeler, düşünceler, anlamlar bütününü özümsemekle kalmayıp bunu kendi düzeyinde yeniden üretmeye de koyulur. Bunun sonucu olarak tek tek bireysel söylemler, iktidarın yaydığ söylemin bir tekrarına dönüşürler ve kişi bir kısır döngü biçimindeki alışkanlıklar çemberi içine oturtulur. Artık böyle bir insandan iktidarın saptadığı davranış ve düşünce kalıplarının dışına çıkmasını beklemek boşunadır; işte La Boétie", kulluklaşan halkın "uyanıp yeniden özgürlüğünü ele geçirmesi olanaksızdır" (s. 257) derken böyle bir beklentinin nè kadar yersiz olduğuna dikkati çekmektedir.

Uyrukların suskunluğundan kaynaklanan bir kabul görme, kurulu düzenin uzun bir yaşama sahip olabilmesi için yeterli değildir. ${ }^{50} \mathrm{La}$ Boétie, "tiranların... halkı yalnızca boyun eğme ve kulluğa değil, fakat körü körüne bağımlılığa da alıştırmaya uğraştıklarını" (s. 268) yazar. Önemli olan yönetilenlerin içinde bulundukları koşulları, yaşam konumlarını benimsemeleri değil, dahası bunları sevip aržulamalarıdır. Gerçeğin -ideolojik anlatımlar süzgecinden geçirilerek algılanması, kişinin kulluğunu, köleliğini bir çeşit özgürlük olarak yaşamasına neden olur. Buna bağımlı olarak siyasal iktidara yönelik derin. bir sadakat (bağlllık) belirir ve siyasal-toplumsal kurallarla kurumlar üzerinde aktif bir consensus yaratılmış olunur.

Bu durum, bir bakıma Hobbes'un Leviathan'ı için öngördüğü kanıların denetlenip güdümlenmesi olgusunu andımr. The Elements of Law adlı yapıtında "dünyanın kanılar tarafından yönetildiğini" ileri süren Hobbes, iktidara kişisel kanıları ortadan kaldırmasını ve kendi düşüncesini bütün yurttaşlara tek doğru, tek meşru düşünce olarak kabul ettirmesini salık vermektedir. ${ }^{51}$ Kurulu düzen için tehlike oluşturabilecek kanıların doğmasını önlemek, özgür düşüncenin yok edilmesiyle olasıdır. $\mathrm{Bu}$ işlemin etkili olabilmesi ise, ideolojik ve kültürel koşullandırmanın başarısına bağlıdır: Kişisel düşünceler resmi ideolojinin bireysel düzeyde yinelenen çeşitli biçimlerine dönüşünce ve kişiler bu düşünceleri özgür istençlerinin ürünleri olarak algılayınca, halk, yalnız bedensel olarak değil, düşünsel olarak da siyasal iktidarın hükmü altına girmiş demektir. ${ }^{52}$

50 Pierre ANSART, Idéologies, conflits et pouvoir, Paris, PUF, s. 212.

${ }^{51}$ Bu konuda daha geniş bilgi için bkz: Raymond POLIN, op. cit., chapitre 9: Thóorie de l'Opinion, s. 205-222.

ऽ2 Marcuse, iktidarın çeşitli yollarla yönetilenlere benimsettiği çelişkilerden arnndırulmış. eleştirel içeriği bulunmayan, hiç bir şey açıklamayan, doğmuyu yanlışı araştırmayıp bünları saptayan, gösteren, kararları ileten birleştirilmiş söylemin, tek boyutlu düşüncenin yaraillmasındaki önemini vurgular. Bu söylemin benimsetilmesinde geliştirilmiş kitle iletişim araçlarının oynadığı rol göz önüne alındığında, günümüzdeki siyasal iktidarların düşünceleri biçimlendirip yönlendirmede La Boétie'nin tiranına ya da Hobbes'un Leviathan'ma göre çok büyük ko- 
Böylece söylemle dışarıya vurulan bu güdümlenmiş "bireysel düşünceler", kurulu siyasal düzenin gereksinim duyduğu aktif desteklere dönüşürler. La Boétie, kitabının başlarında iktidarın ortadan kaldırılması amacıyla halka "Onu itmenizi ya da dengesini bozmanizl istemiyorum. Fakat yalnızca onu desteklemeyin." (s. 253) şeklinde öğüt verirken siyasal iktidarın ayakta kalmasının halktan aldığı desteklere bağlı olduğunu vurgulamaktadir.

Bağımlılık ilişkilerinin hakim ideoloji aracılığıyla gözlerden saklanması, bu ilişkilerin daha kolay ve daha sağlam bir biçimde sürdürülmesini sağlar. İnsanların bilinçsizce yaşadıkları bu ilişkiler ağının güçlenip toplumda çeşitli alışkanlıklar yaratması ise, siyasal iktidarın kök salması, bir başka deyişle "kaidesinin" sağlam temeller üzerine oturtulması demektir. Eğer bu yapılmazsa, La Boétie'nin büyük bir heykele benzettiği iktidar "altındän kaidesi çekilmişcesine... tüm ağırlığıyla düşüp parçalanır." (s. 253). İşte bundan dolayı siyasal iktidar, özgürlüğü ortadan kaldırmakla yetinemez: Gerçeği çarpıtıp bağımlılı̆̆ın özgürlük biçiminde algılanılmasina çalışmak, bunu gerçekleştirmek zorundadır; bunu gerçekleştirebildiği için de vardır. Ancak bu noktada bir yanılgıya saplanmamak gerekir. Karşımızdaki iktidar, La Boétie'nin de belirttiği gibi şu ya da bu siyrasal rejimi karşılamaz; o, kuramını en açık bir biçimde Hegel'in yaptığı modern devlettir, uyruklarına kendisine olan bağımlılıklarını özgürlük olarak yaşamalarını aşılayan devlettir. ${ }^{53}$ Nasıl ki kölelik kurumunun olması (ve Spartacus gibi istisnaların ortaya çıkmaması) için kölelerin köleliklerini benimseyip sürdürmeyi istemeleri gerekiyorsa, siyasal iktidarın kurumsallaşması için de yönetilenlerin bağımlılıklarını sevmeleri ve bu durumu kendi katkılarıyla yaşatmaları gerekmektedir.

Her ne kadar La Boétie'nin siyasal iktidar çözümlemesi sosyal sınıf- ların varlığını dışlamaktaysa da, şimdiye değin gönüllü kulluk olgusunu açıklamaya yönelik olarak ortaya koyduğumuz saptamaları (iktidarın meşruluk kazanması, yetkeye dönüşmesi, ideolojik söylemiyle aktif consessus'ü yaratması vb...) tek bir kavram altında, Gramsci'nin sınıf iktidarını

layluklara sahip olduklan görülür. Daha geniş bilgi için bkz.: Herbert MARCUSE, l'homme unidimensionnel, Paris, Minuit, 1970, s. 119-140.

s? HEGEL, Principes de la philosophie du droit, Paris, Idées/Gallimard, 1973.

George ORWELL'in, 1984 (Paris, Folio/Gallimard, 1977, s. 15) adl yapitindaki "Savaş barıştır" ya da "Özgürlük köleliktir" biçiminde sloganlar kullanan ve halkının bunlan özümsemesini sağlayan devlet, gerçeğin söylemsel düzeyde çarpıtılmasının en uç noktadaki örneǵini oluşturur. Ancak günümüzdeki devletlerin "barış amacıyla savaşlar" yaptıklarina ve "özgürlüğü savunmak için yeni yeni kısıtlamalar" getirmelerine bakıldığında, bu anti (ya da kara) ütopyada çizilen modelden pek uzakta olmadığımız görülür. 
irdelemede kullandığı "hegemonya" kavramı altında toplamak mümkün.54 İktidarn sınfsal boyutuyla ilgilenmeyip La Boétie'yle birlikte sorunun özüne inildiğinde, iktidarın iki ayrı düzeyde, yani hem siyasal toplum hem de sivil toplumda gerçekleştiği ya da gerçekleşmek zorunda olduğu görülür. Gramsci, kurumsallaşmı̧ siyasal iktidarı (devleti) şöyle tanımlar: "Devlet=siyasal toplum+sivil toplum, yani zorlamayla zırhlanmış hegemonya. Tam anlamiyla devlet=diktatorya + hegemonya." Bir toplumdaki yönetenler kesiminin (ki bu ister bir hanedan, ister bir sinıf, ister bir parti olarak görülsün) gerçek anlamda iktidar olabilmesi, siyasal aygitı elde tưtmasının dışında kültürel-ideolojik yapıya da hakim olmasına bağlıdır. Bu durum, siyasal toplumdaki zorlama, hükmetme işlevine sivil toplumdaki hegemonya işlevinin eklenmesidir.

Yöneten sinıf, genellikle "özel" olarak kabul edilen çeşitli aygıtlar (ki 16. yüzyılda bunların en önemlisi kilisedir) aracılığıyla toplumun kültürel yönetimini elinde tutup hegemonyasını gerçekleştirir. Halk kitleleri üzerinde entellektüel bir denetim kurulur: İdeolojik yönlendirme-güdümleme yoluyla onlara yeni değerler, yeni bir dünya görüşü" (Weltanschauung) benimsetilir, kültür aşılamasıyla da "popüler kültür" ya da halk arasında yaşanan "ikincil ideolojiler" yozlaştırılıp yeniden biçimlendirilir. Böylece kitlelerin, toplumun (yönetenler-yönetilenler biçimindeki) bölünmüşlügünü haklı görmeleri ve kurulu düzeni onaylayıp desteklemeleri sağlanmış olur.

Görüldüğü üzere, hegemonyanın kurulduğu ideolojik düzey, zorlamayı, şiddeti dışlamakta ve onamaya, consensus'e yönelmektedir. İktidarın baskıya, fiziksel şiddete başvurması, genellikle hegemonya işlevinin başarısız olduğu anlamına gelir. Ancak böyle bir durumda bile hakim ideoloji, halkın bu uygulamayı meşru olarak görmesini sağlar. Tıpkı zorla kabul ettirilen kuralların daha sonra alı̧̧kanlıklar yaratarak ideolojiye dönüşmesi gibi, iktidarın olası bir şiddet kullanımını çok önceden doğrulayıp meşru kılmasıyla toplumsal bir kesimin, hatta halkın tümünün üzerinde uygulanan bir baskı, onaylanıp kabul görür. Dahası çeşitli (maddi ve manevi) biçimler altında beliren bu "meşru" şiddet, halk tarafından özümsenerek yaşamın ayrılmaz bir parçasına dönüşür.

Söylev'deki halk "en güzel ve en parlak kazançlarının götürülüşüne, tarlalarının yağmalanmasınã, evlerinin ve eşyalarının çalınmasına seyirci

\footnotetext{
\$4 Antonio GRAMSCI'nin hegemonya kavramıla ilgili olarak başvurulan yapitlar sunlardır: Norberto BOBBIO ve Jacques TEXIER, Gramsci ve Sivil Toplum, Ankara, Savas, 1982, s. 75-78 ve diğer bölümler; Hugues PORTELLI, Gramsci ve Tarihsr! Blok, Ankara, Savaş, 1982, s. 67-96; Christine BUCI-GLUCKSMANN, Gramsci et l'Etat, Paris, Fayard, 1975, s. 114-138 ve 205-230; Maria-Antoniette MACCIOCCHI, Pour Gramsci, Paris, Seuil, 1974, s. 159-199; Jean-Marc PIOTTE, La pensée politique de Gramsci, Paris, Anthropos, 1970, s. 223 ve sonrasi.
} 
kalmaktan" da öte "tiranlar yağmaladıkça... yakıp yıktıkça onlara daha çok şey vermekte ve daha çok hizmet etmektedir." (s. 252-253). La Boétie'nin 450 yll önceki bu saptamasının hâlâ geçerliliğini koruduğunu ileri sürmek mümkün: Günümüzde de halkın üzerinde uyguladığı maddi içerikli şiddeti özveri olarak adlandırmayan ve ondan daha çok özveride bulunmasını istemeyen bir iktidardan söz edilebilir mi? Şiddeti çağrıştıran bir ortamda, bombaların gölgesinde yaşamayı bir alışkanlık haline getirmemiş ve benimsediği siyasal rejimin kendisinden istediği özverilere gönülden katlanmayan bir halkın bulunduğu söylenebilir mi? Demek ki halkın ideolojiye dönüşen bu şiddete böylesine koşullanması, hegemonyanın zayıflığını göstermek şöyle dursun, tam tersine onun ne denli sağlam bir biçimde yerleştiğine ilişkin kanıtı oluşturur.

Özgürlügün yok oluşu ile siyasal iktidarın belirmesi arasında bir koşutluk vardır. Bu noktada ise hegemonyanın kurulmasıyla birlikte gönüllü kulluk olgusunun ortaya çıtı̆̆ı görülmektedir; daha doğrusu iktidarın ideolojik başarısı sonucu yaratılan bu yeni ortam, iktidar açısından hegemonya adını alırken halk düzeyinde gönüllü kulluk olarak belirir. Artık, dünya görüşleri, düşünceleri, davranışları biçimlendirilmiş ve hatta üstlerindeki baskıyı bile onaylatan bir koşullandırılmaya uğramıs insanların, "özgürlüğü değil de köleliği kaybetmişcesine... çok içten ve istekli bir biçimde kulluk (hizmet) etmelerini" (s. 257) ya da siyasal iktidarı "yerinde tutmak ugruna canlarını vermelerini" (s. 258) görmek şaşırtıcı olmasa gerek.

Hegemonya, ilk bakışta salt bir ideolojik olgu gibi görünmesine karşin, iktidarın politikası, yönetimin kararları ve uygulamaları tarafından da belirlenmektedir. Sözler consensus'ü yaratmada ya da sürdürmede yetersiz kalabilir ve genellikle bu böyledir. Bu durumda bazı olguların, belirli toplumsal edimlerin ideolojik yönlendirmeyi desteklemeleri gerekir. Böylece, ideoloji, söylemsel düzeyin sınırlarını aşıp eylemsel düzeye girer. Ancak bu destekleyici edimlerle pratikler, ideolojik söylemin içerdiği tasarımlamn, imgelerin, mitosların somutlaştırılmı̧ biçimleri olabilecekleri gibi, bu içerikten tümüyle bağımsız da olabilirler ve böylece hakim ideolojinin güçlenmesine "dışarıdan" katkıda .bulunurlar. Iktidarın halk kültürünün maddi koşullarını değiştirmesi, kültür aşllama işlemini kolaylaştırarak halk kültürünün daha büyük bir dönüşüm geçirmesine neden olur; buna bağıml olarak da kitlelerin hakim ideolojiye daha duyarlı kılınması ve toplumdaki hegemonik etkinliğin arttırılması sağlanır.

55 Buna en iyi örnek, özgürlük ideolojisinin sürmesine karşu bunun iktidarın hakim ideolojisi tarafından yozlaştırıldığından dolayı, kişilerin bağımlılıklarını özgurlük biçiminde yaşamalarıdır. 
La Boétie, tiranların uyruklarını alıklaştırmak ve gönüllü kulluğu sürdürmek için pratik alanda kullandıkları yöntemleri, iktidarın kurnazlıkları, hileleri olarak adlandırır. Eğitim ve alışkanlıkla (yani ideolojiyle) özgürlüğü unutan ve kul-köleliği benimseyen insanlar, "ağızlarına çalınan iki parmak bal ile" içinde bulundukları duruma gönülden bağlanıp onu kendi arzularıyla sürdürürler. ${ }^{56}$ İktidarın başvurduğu yöntemlerden ilki, halkun zevk ve eğlenceye düşürülmesi, boş şeylerle oyalanmaya yönlendirilmesidir: "Tiyatrolar, oyunlar, eğlenceler, gösteriler, acaip hayvanlar, madalyonlar, tablolar ve diğer uyuşturucular eski halklar için kulluklaşmanın yemi, özgürlüğü yitirmenin bedeli, tiranlığın araçlarıdır." (s. 264) Kendilerini böyle bir yaşama kaptıran ve bundan haz duyan insanlar, siyasal iktidarın işine gelen bir niteliğe bürünürler: "Effemine" (kadınımsı) olurlar, gevşeyip yumuşarlar. ${ }^{57} \mathrm{La}$ Boétie'nin deyişiyle, artık "alçak ve yumuşak olan yürekleri büyük şeyleri (yani, özgürlüğe kavuşmak uğruna herhangi bir eylemi) yapabilmekten yoksundur." (s. 263). Söz konusu olan bu durum, insanların maddi temelleri yaratılmış yeni bir kültürün içine oturtulmasıdır, bir bakıma hegemonyanın gerçekleşmesidir.

Kulluğu sevdirmeye yönelik bir başka yöntem, iktidarın "paternalistpopülist" bir görünüm alarak halka belli maddi çıkarlar. sağlamasıdır. Poulantzas'a göre consensus, her zaman için maddi bir temele sahiptir. Siyasal iktidar (devlet) yalnızca "baskı-idəoloji" ikilisine indirgenemez; faşizm gibi en katı rejimler bile kitlelerle ilgili olarak bir dizi olumlu önlemler almak zorundadır. Ancak bu durum, kitlelerin sömürüsünü engellemediği gibi bu sömürünün (göreceli artı-değer yoluyla) daha da artmasına neden olur. ${ }^{58}$ La Boétie de iktidarın "eli açık davranışlarının" ardında yatan gerçeğin bilincindedir ve bunu açıkça belirtir: Yiyecek-içecek dağıtılması, para bağışlanması ya da şölenler düzenlenmesi gibi uygulamalar, tiranların, halkı sömürerek elde ettiklerinin ufak bir bölümünü halka geri vermelerinden başka bir anlam taşımaz. “... Özgürlüğ̈üe yeniden kavuşmak amaciyla çorba tasını terketmeyi akıl edemeyen" (s. 265) halk, yalnızca kısa vadedeki çıkarını gözettiğinden dolayı, iktidarın kul köle olmakta ve sömürü mekanizmasının içine iyice gömülmektedir.

- $\overline{\$ \mathrm{Bu} \text { bölümde La }}$ Boetie'nin halka karşı çok acımasız bir tutum içinde olduğu görülür: "(Halk) kendini sevene karşı kuşkulu, kendisini aldatana karşı ise saftır. Ağızlarına çalınan iki parmak bal ile cezbedilen halklar kadar, ne avcı düdüğüne kanıp tuzağa düşen saf bir kuş, ne de yem için oltaya takılan alık bir balık olabileceğini düşünmeyin." (s. 264).

57 Söylev'in çeşitli bölümlerinde yüreksiz, zayıf, alçak olmakla kadınımșı (ya da kadın) olmanın bir tutulmasł, La Boétie'nin kadınlar hakkında olumlu görüşlere sahip olmadığın göstermektedir.

${ }_{53}$ Nicos POULANTZAS, op. cit., s. 34-35 ve 179-217. 
İktidar, halk için yeni bir yaşam biçimi ve buna uygun bir ideolojikkültürel yapi oluştururken, yeni "halk kültürü"nün cehaleti yaygınlaştırıcı bir nitelik taşımasına da özen gösterir. Bu amacın gerçekleştirilmesinde ise kendisine bağlı aydınlardan yararlanır. "İktidardaki grup, aydınları yalnızca kitlelerin desteğini kazanmak için değil, dahası kitleleri ideolojik ve moral düzeyde kendi dünya görüşüne uygun şekilde biçimlendirmek için kullanır." ${ }^{9}$ Hegemonyanın kazanılmasından ve sürdüiülmesinde aydınların oynadı $\breve{ı}$ role dikkati çeken Gramsci, iktidar mücadelesinin ilk önce ideolojik olmasından dolayı, hakim sınıfın yönetilenleri bilinçlendirebilecek bağımsız aydınların ortaya çıkıp sivil toplumda etkili olmalarını önlemeye çalıştığını belirtir. ${ }^{60} \mathrm{Bu}$ konuda daha çok Sokratesçi-Platoncu yaklaşımı izlediği görülen La Boétie'ye göre, "İnsanların kendilerini tanımalarına ve tiranlıktan nefret etmelerine yardımcı olacak" (s. 261) bilge kişilerin, aydınların, iktidar tarafından sınırlandırılıp denetlenmeleri olgusu, gönüllü kulluğun sürdürülmesine katkıdä bulunan önemli etmenlerden birini oluşturmaktadır.

Fakat La Boétie, bu saptamasıyla yetinerek konuyu derinleştirmeye kalkışmaz ve iktidarın ideolojik-kültürel alanı yönetip yönlendirme işleminde somut olarak kimlerden yararlandığına ilişkin soruna değinmez. Ancak, her ne kadar Söylev'de açıkça görülmüyorsa da, hakim dinsel-ideolojik söylemle hurafeler yayıp halkı saçma sapan inançlara iten din adamlarının, (Gramsci'nin deyişiyle) "iktidarın organik aydınlarn". biçiminde algılanıldığını ileri sürebiliriz. Çünkü La Boétie, ("kilise" sözcüğünü hiçbir zaman kullanmamasına karşın) Machiavelli ya da Hobbes'u andırırcasına siyasal iktidar ile din arasındaki yakın ilişkiyi gözler önüne sermekle kalmaz, dinin bir çeşit toplumsal uyuşturucu işlev gördügünü de vurgular: "Tiranlar, dini koruyucu olarak ön plana koymayı arzular ve hatta, mümkünse, kötü yaşamlarına destek olması için birką̧ tanrısallık örneğinden yararlanırlar" (s. 267).

La Boétie, bu noktada eleştirilerini özel bir alana yönlendirip Fransız Monarşisi'ni hedef alır. Dolaylı ve ironik (alaycı) bir dil kullanarak Fransız krallarının tiranlardan aşağı kalır bir yanları olmadıklarını vurgular: Buradaki siyasal iktidar da dinin yardımına başvurmuş ve kendisini dinsel ve kutsal içerikli imgelerin, simgelerin, tasarımların oluşturduğu bir

59 M.A. MACCIOCCHI, op. cit., s. 213.

60 Gramsci'nin aydınlar sorununa ve kilise adamlarının entellektüel işlevine ilişkin görüşleri için, 54 ,no.lu dipnotta verdiğimiz kaynakçanın dışında, özellikle şu kitaplare başurulabilir: Antonio GRAMSCI, Aydinlar ve Toplum, Istanbul, Ornek Y., 1983; Antonio GRAMSCİ, Modern Prens, Ankara, Birey ve Toplum Y., 1984; Hugues PORTELLI, Gramsci et la question religieuse, Paris, Antropos, 1974. 
giz perdesiyle örtmüştür. ${ }^{61}$ Ronsard, Du Bellay gibi ozanlar yarattıkları mitoslarla iktidarın çevresine örülmüş olan bu perdeyi daha da kalınlaştırmışlar ve iktidarın laik organik aydınları olarak halkın bu "gizin etkisiyle hizmet etmeye alışmasına" (s. 266) katkıda bulunmuşlardır. Kraliyet buyruk ve fermanlarında açıkça görülen bir çeşit "çift dil" kullanımı ise, yapılan her türlü baskının halkın iyiliğini gözeten bir uygulama biçiminde anlaşılıp algılanılmasını sağlamıştır. La Boétie için her siyasal iktidar, bir "iktidar imgesi" yaratmaktadır. Bu yönde kullanılan yöntemler, teknikler, değişiklik gösterebilir; ancak iktidarın özü hiç değişmediğinden dolayı hep aynı sonul amaç güdülmektedir: Uyruklarda saygı ve hayranlık doğurarak kurulu düzenin, yönetenler-yönetilenler ilişkilerinin güvence altında sürdürülmesi.

Söylev'in bu bölümünde gönüllü kulluk olgusu, bir inanç sorunu olarak belirmektedir. İdeolojik söylemler, pratikler ve çeşitli yöntemler (örneğin, iktidar sahiplerinin Asur kralları ya da Orwell'in big brother'ı gibi kendilerini halka hiç göstermemeleri, ya da günümüz devlet adamlarının gelişmiş kitle iletişim araçları yoluyla sürekli kendilerini gösterip kişilere doğrudan doğruya hitap etmeleri gibi farkl, hatta karşıt yöntemler) iktidar üzerinde olumlu bir inancı ya da daha doğrusu salt bir biçimde iktídar inancını yaratır, besler ve yeniden üretirler. Demek ki iktidarın hegemonik olmasıyla birlikte insanlar, iktidara yalniźca fiziksel olarak degil, duygusal olarak da bağlanırlar ve bunun sonucunda iktidar olgusunun içerdiği kulluk-kölelik ağının içine kendi istekleriyle saplanıp kalırlar. Ancak, buraya kadar söylediklerimiz gönüllü kulluğu açlklamada yeterli değildir. Bunun gerçekleşmesi için gereken zorunlu bir koşul daha vardır: $\mathrm{Bu}, \mathrm{La}$ Boétie'nin tanımıla "hükmetmenin desteğinin ve temelinin" kurulması ya da bir başka deyişle siyasal iktidarın kurumsallaşıp, merkezileşip egemen devlet olarak belirmesidir.

\section{DEVLET}

La Boétie'ye göre gönüllü kulluk olgusu, halktan değil de yönetimden ya da Söylev'deki adlandırmayla "tiran"dan kaynaklanmaktadır. Ancak Söylev, ikinci bölümde belirttiğimiz üzere, tiranın ardında devletin, "bir"in iktidarı ardında da devlet gücünün (kudretinin) bulunduğunu ortaya koymaktadır. Bir başka deyişle, La Boétie'nin tiranlığa, zorbalık ik. tidarına karşı yönelttiği eleştiri, çok daha derin ve kapsamlı bir eleştiriyi,

${ }^{\overline{11}}$ Doğu ERG广L' in belirttiği gibi "ister dinsel olsun, ister laik olsun, ideoloji, kutsal olanla ilgilidir." Bkz:: "Ideoloji Uzerine Düşünceler" in S:yasal Bilgfler Fakültesi Dorgisi, Ocak-Aralık 1983, N. 1-4, s. 73. Fernand DUMONT "Ideolojik pratiklerin her zaman herhangi bir aşkınlığa (transcendance) basvurdukların”" yazar. Bkz.: Les idéologies, Paris, PUF, 1974, s. 111. 
kısa bir süre sonra siyasal kuramcıların ve devlet adamlarının "egemenlik" diye adlandıracakları modern devlete özgü gücün eleştirisini içermektedir. Söylev'de egemenlik kavramı kullanılmaz; çünkü bu kavramın be'lirmesi için 1576 yllını beklemek gerekir. ${ }^{62}$ Fakat La Boétie, bu kavramı bilmemesine karşın, siyasetin doğasını çözümlemeye uğraşırken, buna bağlı olarak egemenliğin de doğasını kavrayıp açıklığa kavuşturur. Bodin, Hobbes gibi çeşitli modern siyasal düşün adamları, devlet gücü (egemenliği) kuramını tiranlığa karşı kurarlarken, La Boétie bunlardan farklı olarak bu gücün doğası gereği ister istemez tiranlığı içerdiğini ileri sürer.

Söylev'de görülen tiranlığı, 16. yüzyılın yaygın rejimi olan monarşiden ve hatta bir bakıma demokrasiden bile ayırmak olası değildir. La Boétie'nin tiranlık çeşitlemesi bunun açık bir kanıtını oluşturur: İktidarın babadan oğula geçişi ya da halkın seçimiyle belirlenmesi hiçbir şey değiştirmez; yönetim biçimi ne olursa olsun iktidarın özü tiranlıktır ve tiranlık kalır. İktidarın gerçek anlamda iktidar olabilmesi, yani kurumsallaşıp yerleşebilmesi için halkı bağımlıh̆ga yönlendirmesi ve kulluğu sevdirmesi gerekir. İşte La Boétie'ye göre bu durum tiranlığın ta kendisidir. Bir başka kanıt, Söylev'deki tiran imgesinin klasik tiran anlayışıyia bağdaşmamasıdır. Her ne kadar La Boétie, yapıtının bazı bölümlerinde tiranı geleneksel anlamı içinde ele alıyorsa da, genellikle tiran ile cgemeni özdeşleştirme yoluna gider. Buradaki tiran, tek başına olup yalnızIığın onda yarattığı korkudan dolayı yalnızca kaba güce, şiddete dayanarak hüküm süren ve deliliğin eşiğinde bulunup keyfince kan döken birisi değildir. ${ }^{63}$ La Boétie, Platon'dan, özellikle de Aristoteles'ten bu yana tiranlığı "doğru" yönetimleri belirlemede bir ölçüt olarak kullanan anlayışa kesinlikle karşı çıkar. Bu nedenle, tiranın iktidarının meşru olmadığını ya da bu iktidarın yasaları çiğnediğini söylemek gereğini duymaz bile. Nasıl olsa tiran egemeden, tiranlık da kurumsallaşmış merkezi siyasal iktidardan başka bir şey değildir.

La Boétie'nin tiranı betimlemede baş vurduğu bir imge, Hobbes'un "Leviathan"ıyla büyük bir benzerlik gösterir. La Boétie, tiranı "iki gözü, iki eli ve bir bedeni" (s. 253) olan sıradan bir insan olarak gösterir. Ancak bir tümce sonra, bu insanın kendisine halk tarafindan verilmiş bir sürü göze, ele ve ayağa sahip olduğunu açlklar. Böylece tiranın görünen bedeni dışında bir başka bedeni daha belirir. Bir benzeri bulunmayan bu

62 1578, "egemenlik" kavramıni siyasal kuram alanına kazandiran Jean BODIN'in Les Six Livres de la République (Devletin Altı Kitabı) adlı yapıtının yayımlanma tarihidir.

63 Gérard MAIRET, "La Genèse de l'Etat laique in Histoire des Idéologies, sous la direction de François CHATELET, Paris, Hachette, 1978, tome: II, s. 303-304. 
beden, hem diğer insanlardan ayrıdır, hem de her şeyi görüp her şeyi yapabildiğinden dolayı, herkesi kendi içinde toplamaktadır. Tıpkı Leviathan'ın ilk basımının kapağında bulunan birçok insan bedeninden oluşmuş "ölümlü Tanrı" resmi gibi, ${ }^{64}$ La Boétie'nin bu tiran betimlemesi de, bir yanda herkesin yazgısını elinde tutan ve yönetilenler kitlesini dışlayan iktidarı, öte yandan tek bir organik kimliğe sahip kütünleşmiş bir siyasal toplumu simgelemektedir. Bir başka deyişle, ayni imge hem bölünmeyi hem de birliği içermekte, iki karşıt işlevi aynı anda yerine getirmektedir.

Salt hükmetme-boyun eğme ilişkisi üzerine kurulan bir iktidar, yalnızca parçalayıp bölmekle yetinir. Oysa her siyasal iktidar, kendini tam bir güvence altına alabilmek için yönetilenlerin onamasını elde etmek, consensus'ü sağlamak zorundadır. Bunun yolu meşruluğun kabul ettirilmesinden geçer ve böylece iktidar, ilk aşamada yoksun olduğu bir boyut kazanır. Ancak gerçek anlamda bir meşruluk, kişi(ler) üzerine değil, yapllar ve bu yapilardan ķaynaklanan ilkeler üzerine kurulabilir. Bu bakımdan, iktidar, kişi(ler) den bağımsız kılındığı an soyut bir temele gereksinim duyan soyut bir birim durumuna dönüşür. Bu temel, devlettir. La Boétie'nin kullandığı bir benzetmeden hareket ederek Colosse'un (büyük Apollon heykelinin) tiranı (yani, iktidarı kullanan kişiyi), onun altındaki kaidenin ise devleti simgelediğini söyleyebiliriz. Bu kişi ile kurum arasındaki ilişkide ağırlık devlete verilmiştir. Çünkü Colosse'u ayakta tu$\tan$ bu kaidedir ve ancak bu kaidenin "desteği" çekildiği zaman Colosse düşüp parçalanır (s. 253). Bu gerçeğin bilincinde olan Machiavelli, egemenin egemen olabilmesi için bir devlete dayanması gerektiğini açıkça vurgulamıştı. ${ }^{65}$ Fransa kralı 14. Louis ise, "devlet benim" deyişiyle, devletin bir insanda beden bulmasını değil, fakat bir insanın devletle özdeşleşmesini, onunla bir olmasını dile getirmişti. ${ }^{\infty}$ Demek ki, iktidarın yasal-meşru bir çerçeve içinde kurumsallaştırılması ve yöntten(ler)in kendini bu kurumla özdeşleştirmesi, egemenliğin kurulmasında ve sürdürülmesindeki en önemli koşul olarak belirmektedir.

Egemenin ve ardındaki kurumun "bir" olarak belirmesi, insanlarm doğanın isteği doğrultusunda birler olmasını engeleyip ortadan kaldırır. Artık birler değil, fakat herşeyi içine çekip emen dünyasal yüce tek "bir" vardır. Bir başka deyişle, insanları yönetenler-yönetilenler biçiminde bölen devilet, aynı zamanda onları, meşruluğunu sağlama yönünde kullandığı ideolojik söylem ve eylemler aracılığıyla bir bütün içinde eritir.

6: Bu resim için bkz. Mete TUNÇAY (derleyen), Batı'da Siyasal Düşünceler Tarihi-2 Yeni Çağ, Ankara, SBFY, No. 228, 1969, s. 119.

as "... hükümdarın tahtı, yasaları, dostları ve onu koruyan devleti vardır." MACHIAVELLI, Hükümdar, op. cit., s. 89.

60 Georges BÜRDEAU, op. cit., s. 47. 
İnsanların kişiliklerini yitirip bireyler olmaktan çıkmalan sonucunda insanlığın yozlaşmasının son evresi de tamamlanır. Böylece La Boétie'nin "zavallı, sefil" olarak nitelendirdiği, kendini bu soyut bütünün ayrilmaz bir parçası biçiminde algılayan ve devlet iktidarının etki alanı içine gömülüp kalan insan yarațlmıs olur.

Ancak modern devlet, insanı bu duruma indirgemekle yetinemez. Íktidarın tek elden kaynaklanmasına koşut olarak, iktidarın her düzeye aynı etkinlikle girmesine olanak sağlayan bir toplumsal-siyasal yapıya gereksinim vardır: Egemenliği tehdit eden (hatta sinılayan) kurumların, yapıların, yerel grupların özerkliği, tıpkı insanlarda olduğu gibi, yok edilmelidir. Bunun dişında devlet, tavandan tabana doğru gelişen hiyerarşik bir örgütlenmeyle merkezileşmeli ve kendine özgü bir yönetici kadroyu, yani bürokrasiyi oluşturmalıdır. 16. yüzyıl başlarındaki Fransız devleti, yukarıda saydığımız bu nitelikleri içeren bir görünüm vermektedir. Modern devletin Orta Çağ'daki kökenlerini inceleyen Strayer, Fransız devletinin 12. yüzyılda "modernleşme" süreci içine girdiğini ve merkezi-bürokratik devlet yapısının 16. yüzyılda çok belirgin bir duruma ulaştığını vurgular. Örneğin, bu dönemde feodal içerikli bağlllıkların (loyalisme) yerini devlete olan bağlılık almış ve iktidardaki kişi(ler)den "bağımsız" bir varlığa sahip bulunian bir devlet aygitı ortaya çıkmıştır. ${ }^{67}$ Leo Huberman ise, merkezi devletin güçlenmesinde kentsoyluların sağladığı desteğe dikkati çeker: "Kral, feodal lordlara karşı kavgaya tutuşan şehirlilerin güçlü bir müttefiki olmuştu. Baronların gücünü azaltan her şey onun gücünü arttırnyordu." ${ }^{\prime 6}$ Ancak gücünü arttıran devlet, bununla yetinmeyip egemenliğin gereği olarak müttefiklerini (bağlaşıklarını) denetim altına sokmakta, kentlerin özerkliklerine sinirlamalar getirmekte ya da bunları tümüyle ortadan kaldırmakta gecikmemiştir.

La Boétie'nin, gerek sinıfsal kökeninden gerekse içinde büyüdüğü toplumsal ortamdan dolayı, siyasal iktidamn ulaştığı bu boyutu kavraması hiç de zor olmamıştır. Yaşadığı Gabelle ayâklanmasının sonuçları da, büyük bir olasılıkla düşüncelerinin olusşumunda etkili olmuştu: Bu ayaklanmanın kanlı bir şekilde bastırılmasından sonra Bordeaux Parlamentosu ile Üniversitesi'nin bir süre için kapatılması, ona devletin merkezi gücü hakkında bir fikir vermeye yeterliydi. İşte, çă̆ındaki bu siyasal dönüşümün önemini algılayan La Boétie, yapıtının son sayfalarını gönüllü kulluk olgusu ile devlet aygıtı arasındaki yakın ilişkiye ayırır. Ona göre, her türlü siyasal iktidar özgưrlüği yok cdici bir etkiye sahip bulunuyor-

$\overline{0 i}$ Bu konuda daha geniş bilgi için bkz.: Joseph R. STRAYER, Les Origines Médiévales de l'Etat Moderne, Paris, Payot, 1979.

as Loo HUBERMAN, Feodal Toplumdan Yirminci Yüzylla, çev. Murat Belge, Ankara, Dost K., 1982, s. 79. 
sa da, insanların köleliği arzulayıp gönülden benimsemeleri ancak iktidarın bütün toplumu kapsayan hiyerarşik bir yapı biçiminde kurulmasıyla mümkündür. Buna göre, gönüllü kulluk, egemen devletin açıķa belirdiği modern çağlara özgü bir olgu olarak karşımıza çıkmaktadır.

Söylev'in bu son bölümünde, tiranın tek başına olmadığından başka salt kaba güce dayanmadığı da görülür: "Tiranı koruyanlar atlı insan bölükleri, yaya insan sürüleri ya da silahlar değildir. İlk bakışta inanmak istenmez, fakat gerçektir: Tirana destek olan ve tüm ülkeyi kulluk altında tutan hep dört ya da beş kişidir. Her zaman için beş ya da altı kişi tiranın gözüne girmiş, gerek kendilerinden gelen istekle gerek tiranın çağırmasıyla ona yaklaşmı̧ ve böylece gaddarlıklarının, eğlencelerinin yoldaşı, zevklerinin pezevengi ve yağmaladıklarının ortağı olmuşlardır.. Bu altı kişinin de çıkar sağladıkları altı yüz kişisi vardır... Bu altı yüz kişi, buyrukları altında altı bin kişiyi tutarlar..." (s. 268-269) Bu bölüm, Gérard Mairet'nin de belirttiği gibi, ${ }^{69}$ Söylev'in ,can alıcı noktasını oluşturmakta ve yapıtın anlamını ortāya koymaktadır: Tiranın hükmetme gücü, onun kişisel yeteneğinden ya da topluma saldığı korkudan değil, fakat ardındaki devlet aygitından kaynaklanmaktadır. La Boétie'nin tiran olarak adlandırdığı kişi, bu aygitın en üst düzeyini işgal etmekte ve bu konumundan dolayı egemen olarak belirmektedir. Tam anlamıyla "bir" olan tiranın kendisi değildir; "bir", tiran ile "yardakçılarının" bütünüdür, yani kiliseden ya da herhangi bir aşkın güçten bağımsız, iktidarın ilkesi (auctoritas) ile kullanışını (potestas) kendi özünde "bir"leştirmiş olan egemen devlettir.

Devlet erki, hükmetme-boyun eğme ilişkilerini piramit biçiminde bir ağ gibi örerek bütün toplumu sarar. Bu "piramidal" hiyerarşinin doruğunda bulunan kişi, La Boétie'nin adlandırmasıyla tiran, bu ağın yardımıyla yalnızca altı bin kişiyi değil, yüz binleri, milyonları kendine bağlar. (s. 269) La Boétie, gönüllü kulluğun gizinin burada yattığını açıklar: Devletin oluşturduğu bu mekanizmadan dolayı her insan, içinde bulunduğu hiyerarşik düzey ne olursa olsun, kendini, devlet erkini kişiliğinde somutlaştıran tiranla özdeşleştirerek bir başkasının efendisi olmayı arzular. Böylece insanlar, "büyük tiranın altında kendilerini küçük tiranlar yapabilmek için çevresinde toplanıp onu desteklemeye başlarlar." (s. 269) Sonuç olarak tiranlık, tüm toplumu baştan aşağı kapsayan toplumsal bir olgu durumuna dönüşür.

İktidar, piramit biçiminde örgütlendikten ve en üstteki "bir"in yönetiminde çeşitli kulluk ve hükmetme kanalları içeren bir siyasal yapı kurulduktan sonra, artık tiranın hüküm sürmek için, kılını bile kıpırdatma-

${ }^{69}$ Gérard MAIRET, Les Doctrines..., op. cit., s. 116. 
sına gerek kalmaz. Çünkü "tiran, uyruklarını birbirlerine kırdırarak kulluklaştırır." (s. 270) Kişilik kaybına uğramış (bir başka deyişle "bir" olma niteliğini yitirmiş) olan ve bundan dolayı bir kişilik arayışı içinde bulunan insan, var olan tek "bir", yani tiran ile kendini özdeşleştirme yoluna gider: Altındaki insanlarm üzerinde hükmünü kurup onlarn efendisi durumua gelir; fakat aynı zamanda, bir üst hiyeraraşik düzeydekilerin kölesidir ve bu böyle sürüp gider. Bunun sonucunda, yetke (otorite) ile itaat etme birbirine bağlanmıs ve herkes, bir zincirin halkalarn gibi, yalnızca adıyla bile büyülendikleri tiranın (ve onun ardındaki devlet egemenliğinin) boyunduruğu altına girmiş olur. Demek ki, tiranın imgesiyle gü̧̧ kazanıp beslenen kulluk istenci, her kişinin bir başkasının önünde "bir"in adını taşıma arzusuna bağlıdır. Insanın belli kişiler karşısında kendini "bir" olarak algılayabilmesinden dolayı hükmetme, bağımsızlık ve özgürlükten çok daha fazla önem kazanır: insanlar başkalarını baskı altında tutmak uğruna kendilerinin kul-köle olmalarına gönülden razı olurlar. Aynı zamanda herkesin tiranla özdeşleşip küçük tiranlar durumuna dönüşmesi, düzenin özümsenmesine ve bu düzenin temelini oluşturan iktidar ilişkilerinin sürekli bir biçimde yeniden üretilmesine yol açar.

Uyrukların büyülenmişçesine tirana-egemene sevgi duymaları, inșan doğasının yozlaşmasının en açık belirtisidir. Düzeni simgeleyen tirana karşı duyulan sevginin yetersiz olması, egemenin belirlediği yasalara karŞı çıkıp bunları çiğnemek anlamına gelir. Bu bakımdan herkes, yasalara uyulup uyulmadığını kontrol edip, başkalarını yasalara olan bağlllık ölçütüyle değerlendirerek, kendiliğinden düzenin gönüllü koruyucusu olur. Söylev'de özgürlüğün yadsınması olarak görülen bu yas̀a sevgisi ya da yasaya bağlılık, her kişiyi egemenin suç ortağı yapar. Tirana boyun eğip hükmetme-hükmedilme ağlarının içine gömülüp kalmak, insanlar arasındaki dostluğun yok olması demektir. La Boétie'ye göre iki çeşit toplum vardır: İnsan ilişkileri birinde komplo üzerine, diğerinde ise dostluk üzerine kurulmuştur. İlkinde insanlar suç ortaklarıdır, birbirlerinden çekinirler; ikincisinde arkadaştırlar, birbirlerini severler. "Hiçbir arkadaşı olmayan" tiran, "dostluk sinırlarnın ötesinde" (s. 273) bulunduğuna göre, hükmetme olgusu dostluğu, arkadaşlığı dışlamaktadır. Bir siyasal toplumda, hükmetmenin bütün toplumsal alanlara yaygınlaştırıldığı göz önüne alındığında, devletin bulunduğu bir yerde artık dostluktan söz edilemeyeceği ortaya çıkar. Gerçekte bütün toplumsal ilişkilerin temelinde belli bir güç-iktidar ilişkisi vardır. Bu nedenle, dostluğu yadsıyacak kadar yozlaşmış, daha doğrusu yozlaştırılmış insanların tiranlığı yok edip yeniden özgürlüğe kavuşmaları olanaksız görünmektedir. Toplum kendini hükmetmenin büyüsüne kaptırmıştır bir kez. Üstelik, La Boétie'nin dostluk yoksunluğunu siyaseti tanımlayan bir ölçüt olarak ele alması, siyasal rejimler arasında bir sınıflandırma yapmanın gereksizliğini de ortaya koymuş olur. 
Bütün rejimlerin ortak bir yanı vardır: Hepsi birer devlettir, hepsi bir devlet aygıtı aracılığıyla iktidar ilişkilerini toplumun bütün düzeylerine yaymış, bir bakıma siyasal toplumu yaratmıs ve böylece dostluğu yok etmişlerdir.

Her ne kadar "bir" ile özdeşleşen insanlar kulluğu benimseyip tirana canla başla hizmet ediyorlarsa da, La Boétie yine de tiranın "yardakçılarl" (yani bir anlamda devlet memurlarn, bürokratlar) ile halk arasında kölelik derecesi açısından bir fark bulunduğunu vurgular. Halk, "yardakçılara" göre "biraz daha özgürdür", daha doğrusu biraz daha az köledir. Çünkü halk, "ne kadar kulluklaştırılmıs olursa olsun yalnızca kendine söyleneni yerine getirmekle yükümlüdür." Oysa, siyasal iktidar odağına yakın olmalarından doliayı hiçbir güvencesi bulunmayan "yardakçıların", "tiranın söylediklerini yapmaları yeterli değildir, onun ne istediğini düşünmeleri ve hatta onu memnun edebilmek için düşüncelerini öngörmeleri gerekir." (s. 270) La Boétie'nin çok sert bir dille eleştirdiği bu kişilerin, sürdürdükleri "sefil yaşamın" karşlığı olarak elde ettikleri tek şey halkın nefretidir: "Doğal olarak, halk katlandığı acıdan dolayı tiranı değil, fakat kendini yönetenleri suçlar... Tüm belalardan, her veba salgınından ve her kitliktan dolayı bunları sorumlu tutar." (s. 274).

La Boétie burada, devletin bir kez kuruldu mu artık yıkılamayacağı görüşünü dile getirmektedir. Görüldüğü üzere, yönetilenlerin köleliklerini özgür olarak yaşarnalamndan ve kendilerini tiranla özdeşleştirmelerinden dolayı, halkın tiranın simgelediği devlete karşı çıkması olanaksızdır. Bu bakımdan halkın kızgınlığı ya da hoşnutsuzluğu, devletin kendisine değil, yalnızca iktidar aygıtına, daha doğrusu bu aygitın çeşitli düzeylerindeki bürokratlara yönelik olmaktadır.

$\mathrm{Bu}$ konuya daha açıklık getirmeye çalışalım: Halk, toplumsal ve siyasal varoluş koşullarını, hakim ideolojik söylemin kendisine yönelik biçimi (ya da biçimleri) içinde yaşar. Köleliği bilinçlerden gizleyerek bağımlılık ilişkilerini devam ettiren efendi olma tutkusu, hakim ideoloji tarafından sürekli canlı tutulur. Bir bakıma, dostluğa son veren özgürlüğün yitirilmesiyle birlikte özgür düşünce yok edilir ve bunun yerini "ideolojik" düşünce alır. Dahası, çeșitli aygitlar yoluyla hakim ideolojiyi yayıp yeniden üreten devletin kendisi de bir ideolojiye dönüşür ve böylece, yönetilenlerin gözünde, toplumsal yaşamı var kılan ve sinıflar ya da sosyal gruplar üstü bir konumu olan yüce ve meşru bir kurum durumuna gelir. Bunun sonucunda, düşünceleri belli kalıplar içine sokulmuş insanlar, devleti, ancak devletin kendisini onlara göstermek istediği biçimde algılayıp değerlendirirler. Artık bu insanların özgür bir eyleme kalkışmalarını, yani devleti yıkarak doğal özgürlüğe yeniden kavuşmalarını beklemek boşunadır. Poulantzas'ın da belirttiği gibi, "ezilen sinıflar, hükmetme siste- 
mine karşı olan ayaklanmalamnı bile, genellikle, hakim meşruluğun çerçevesi içinden yaşarlar."70

La Boétie'ye göre bu durum, genelde olmayıp hep böyledir. Zaten bu nedenden dolayı La Boétie, 1548 yılındaki Gabelle ayaklanmasını önemsemeyip buna yapıtında yer vermez. Gerçekten bu tarihte vergi yüzünden ayaklanan köylüler, devleti yadsımak şöyle dursun monarşiye bile saldırmazlar. Karşı çıktıkları, kral ile kralın ardındaki iktidar aygıtıdır, özellikle de yeni bir vergiyi geleneklere uymayan yöntemlerle toplamaya çalışan vergi memurlarıdır. ${ }^{71}$ (yani, iktidar aygıtının maliye bölümünde yer alan "yardakçılar"dır). Bu vergi sisteminin feodal özerkliklerin ylkılmasına ve devletin merkezileşmesine katkıda bulunan bir araç olduğu gözönüne alındığında, Gabelle ayaklanmasının "tutucu" olmakla birlikte belli özgürlükleri savunucu bir nitelik taşıdığı söylenebilir. Ancak La Boétie açısından bu ayaklanmanın, devlete içkin bağımlılık ilişkilerinin yıkımını hedef gütmemesinden dolayı, özgürlük ile hiçbir ilişkisi olamayacağı kesindir. Halk, düzenin gerektirdiği herhangi bir uygulamaya ya da karara karşı ayaklanabiliyorsa da gönüllü kulluk zihniyetiyle düşünüp hareket ettiği için sorunun özünü kavrayamamakta ve bu nedenle toplumun bölünmüşlüğünü ortadan kaldıracak yapısal bir, değişikliği gerçekleştirememektedir. La Boétie'nin bu konudaki düşüncelerini açıkça dile getiren kişinin Fransız filozofu Simone Weil olduğunu söylemek mümkün. Ona göre "Güç fazla sayıda olanda değildir. Fazla sayıda olan halk parçalanmış, bölünmüş, dağalmış oldúğu için bir eylem gerçekleştiremez. Ancak ender zamanlarda tek bir beden gibi hareket eder, fakat bu durum uzun sürmez... Kitle yeniden bireylere parçalanır, yengiye gölge düşmeye başlar ve yavaş yavaş eski düzen ya da ona benzeyen bir düzen oluşur. $\mathrm{Bu}$ arada efendiler, hükmedenler değişmiş olsa bile, boyun eğenler hep aynidir."'2

Demek ki insanlar, kurumsallaşmış siyasal iktidamn ortaya çıkmasıyla birlikte kısır bir döngü içine gömülürler: Köleliğe gönülden-bağlandıkları için kendilerini özgürlüğe kavuşturacak bir eylemde bulunamazlar; böyle bir eylemde bulunmadıkları (La Boétie'nin deyişiyle, tirana destek olmaktan vaz geçemedikleri) için de kul-köle durumunda kalıp yitirdikleri özgürlüğü yeniden ele geçiremezler. Bu bakımdan tirandan, daha doğrusu bu somut "bir"in ardındaki soyut "bir"den, yani devlet egemenliğinden bu dünyada kurtulmak olanaksız görünmektedir. İşte bu sonuca

${ }^{70}$ Nicos POULANTZAS, Pouvoir politique et classes sociales, Paris, Maspero, 1971, cilt 2, s. 45.

71 Brian SINGER, op. cit., s. 220.

72 Simone WEIL, "Extrait de Oppression et Liberte, in LA BOETIE, Discours., op. cit., s. 90 . 
ulaşan La Boétie, yapllacak başka bir şey olmadiğına kanaat getirmişcesine tiranların cezasını öte dünyaya havale ederek yapıtını noktalama yoluna gider.

\section{SONUÇ}

Her ne kadar Söylev çaresizliğin bir ifadesi biçiminde son buluyorsa da, yapıtın bazı bölümleri dikkatlice okunduğunda bu kısır döngüden kurtulmanın kesinlikle olanaksız olmadiğı ve ufak da olsa yine de bir çıkış yolu bulunduğu görülür. Bunu açıklamak için La Boétie'nin düşüncelerini çarpitmamaya özen göstererek açmaya çalışalım: Gördüğümüz gibi kulluk istenci, özgür düşünme ve akıl yürütme yetisi ellerinden alınmış insanların zihnine yerleştirilmiştir. Bir bakıma insanlar, siyasal iktidar mekanizmasının ideolojik koşullandırmasıyla ergin olmama durumuna indirgenmişlerdir. Dolayısıyla özgürlük, gönüllü kulluk olgusunun zihinlerden sökülüp atılmasıyla mümkün olabilir. Bir başka deyişle, özgür olmak için ideolojinin (daha doğrusu, hakim ideolojinin) dışına çıkmak gerekir; bu durum, insanın bilimle güçlenmiş aklını kendi başına kullanarak özgürce düsünce üretmesi ve düşüncesinin özgür olmasından dolayı da özgürlüğü bilip onu sevmesi demektir. Soruna bu açıdan yaklaşıldığında, La Boétie'nin Aydınlanma Çağı'nın uzak bir öncüsü olduğu ve Kant ile aralarında çarpıcı benzerlikler bulunduğu ileri sürülebilir. Örneğin Kant, Söylev'den yaklaşık 230 yıl sonra yazdığı "Aydınlanma" hakkındaki makalesinde şöyle demektedir:' "Aydınlanma, insanın kendi suçu ile düşmüş olduğu bir ergin olmama durumundan kurtulmasıdır. $\mathrm{Bu}$ ergin olmayıs durumu ise, insanın kendi aklını bir başkasının kılavuzluğuna başvurmaksızın kullanamayışıdır... Her şey için nerdeyse ikinci bir doğa* yerine geȩen ve temel bir yapı oluşturan bu ergin olmayıştan kurtulmak çok güçtür. Hatta insan bu duruma seve seve katlanmıs ve onu sevmiştir bile." ${ }^{.3}$

İnsanların büyük çoğunluğunun bu durum içinde kalıp akıllamnı kullanamadıklamıı açıklayan Kant, "zihinsel yanlarını kendi başlarına işleyip kullanarak ergin olmayıştan kurtulan ve güvenle yürüyebilen pek az kişi"nin bulunduğunu da vurgular. ${ }^{74} \mathrm{La}$ Boétie'ye göre ise, "ayak takımı" olarak nitelendirdiği halkın özgür düşünemediğinden dolayı özgürlügü sevmesi şöyle dursun, onu anımsaması bile olanaksızdır. Halkın "bilge olmak istememesi acınacak bir şey değil midir?" (s. 273). Ancak, "her dönemde, diğer insanlardan daha iyi doğmuş bazı kişiler bulunur. Bunlar boyunduruğun ağırlığını hissedip sürekli ondan kurtulmaya çalışırlar...

\footnotetext{
- Altın biz çizdik.

${ }^{73}$ Immanuel KANT, " "Aydinlanma Nedir?" Sorusuna Yanit", in Felsefe Yazilan. Ist., Yazko, 6. Kitap, 1983, s. 139-140.

74 İbid., S. 140.
} 
Kendiliğinden iyi bir kafa yapısına sahip olan bu kişiler, kafalamn eğitim ve bilgiyle daha da sağlamlaştırmışlardır. Bu kişiler, özgürlük yeryüzünde tümüyle yok olsa bile, özgürlüğü düşleyerek, hissederek ve halâ onun tadını duyarak kölelikten (ki bu süslenip püslense de yine) en ufak bir tat alamazlar." (s. 261) Bir çeşit "entellektüel elitizm"i benimseyen La Boétie, bütün umudunu bu bağımsız düşünebilen birkaç kişiye, bu bir avuç aydına bağlar. Kendisi de bir aydın olarak yapıtında, söylediklerini anlamayacak halk yığınlarına değil, fakat bilgi ve okumakla sağlam kafalara sahip olmuş ve gönüllü kulluk zihniyetiyle yozlaştırılmamış kişilere seslenmeyi yeğler gibidir.

Devlet, uyruklarını ergin olmama durumunda tutarak egemenliğini sürdürmeyi başarır. Kişiler bir anlamda "kendi rızalanyla" erginleşmemiş olarak kalırlar ve kulluğa gönüllü bir biçimde bağlanırlar. Çünkü ergin olmama durumu çok rahat bir yaşam sağlar. İnsanlar üstlerinden büyük sorumlulukların alındığını görürler; artık devlet, onlarn yerine düşünmekte, kararlan almakta ve en ufak bir kuşkuya yer vermeyecek biçimde herkesin davranıslarını daha önceden belirleyip düzene sokarak yarnnlar da kapsayan bir güvenlik ortamı yaratmaktadır. Kant bu konuya ilişkin görüşlerini şöyle belirtir: "Benim yerime düşünen bir kitabım, vicdanım yerini tutan bir din adamım, perhizim ile ilgilenerek sağlığım için karar veren bir doktorum oldu mu, zahmete katlanmama hiç gerek kalmaz artık. Para harcayabildiğim sürece düşünüp düşünmemem de pek o kadar önemli değildir; bu sıkıcı ve yorucu işten başkaları beni kurtaracaktır çünkü." ${ }^{5} \mathrm{La}$ Boétie ise bu durumu, insanm "rahat yaşamak uğruna herhangi bir güvenceyi (özgürlükten-çev.) daha çok sevmesine izin vermiyorum" (s. 251), diyerek dile getirir. Fakat gördüğümüz gibi özgürlüğü, bağımsızlığa ve bağımsızlığın sağladığı rahat yaşama yeğleyebilen yalnızca bilge bir azınlıktır.

Bununla birlikte, aydınların varlığı da, tek başına, özgürlük ateşinin yanmasına yeterli olmayabilir. La Boétie, Osmanlı Devleti'nden söz ederek "Büyük Türk"ün buyruğundaki aydınların birbirlerini tanımadıklarından dolayı özgürlüklerini yitirdiklerini ve fantezilerinin içinde yalnız başına kaldıklarını vurgular (s. 261). Demek ki, aydınların hem siyasal iktidardan bağımsız olmalan, hem de karşıllklı tanıma mekanizması yoluyla dostluk ilişkileri kurmaları ve böylece kendi özlerini, yani insanın özgün doğasına içkin olan özgürlüğü algılamaları gerekmektedir. Bu aşamaya gelen aydınların karşısına bir başka sorun daha çıkar: İdeolojiyle koşullandırılmış bilgisiz halk yığınlarını özgürlüğü sevmeye yöneltmek. Aydınlar kendi aralannda bir çeşit komplo kurup tiranı, yöneticileri yıksalar bile, gönüllü kulluk sorununu çözüme kavuşturmuş olamazlar. Kant'- 
In da belirttiği gibi, "gerçi devrimler ile bir baskı rejimi, kişisel bir despotizm, bir zorbalık yönetimi yıkılabilir; ancak yalnız bunlarla, düşüncelerde gerçek bir düzelme, düşünüş biçimlerinde ciddi bir iyileşme elde edilemez; tersine, bu kez yeni önyargılar, tıpkı eskileri gibi, düşüncesiz yığına, kitleye yeni bir gem, yeni birer yular olurlar."76

Söylev, böyle bir siyasal devrim olasılığindan söz etmez bile. La Boétie'ye göre insaṇların zihninde bir çeşit "kültür devrimi" gerçekleştirilmedikçe, halkın aydınları izlemesini beklemek boşuna olur. Çünkü devlet, toplumu, kurduğu bağımlılık ilişkileri zinciriyle ve yeniden ürettiği hakim ideolojiyle sürekli bir denetim altında tutmakta ve bireylerin erginleşmesini önlemektedir. Bunun sonucu olarak, köleliklerini özgürlük şeklinde algilayan insanlar, özümsedikleri tiranın ölümünün ardından ağlayıp kendilerine özgürlük getirmek isteyenlere karşı koyarlar. ${ }^{\pi}$ Aklını kullanıp. özgür düşünen birkaç kişinin halkın kulluk istencini değiştirme gücü bulunmadığına göre ne yapılmalıdır? Bu bağlamda La Boétie'nin, Brutus, Cassius gibi tarihsel kişileri överek ister istemez terorizme kaydığ görülür: ${ }^{78}$ Her ne kadar Brutus ve Cassius ile birlikte (Roma'daki) cumhuriyet tarihe gömülmüşse de, bu büyük darbeciler onurlu ölümleriyle, özgürlük yolunda yapılan eylemin erdemini göstermişlerdir (s. 262). Böylece Söylev, aydınların çeşitli eylemlere kalkışarak ve hatta özgürlük uğrunda ölmeyi ve öldürmeyi göze alarak, halkın üzerine serpilmiş ölü tozunu silkelemelerini ve en azından zihinlerde kurulu düzene ilişkin bazı soru işaretleri yaratmalarını salık verir gibidir. Bu aynı zamanda, ikiyüzyıl öncesinden "Aydınlanma"ya ışık tutan genç bir aydının, aydınların topluma karşı olan sorumluluklamnı dile getirmesidir.

76 Ibid., s. 140.

77 "Entellektüel elitizm"in en büyük kuramcısı olan Platon, bilge kişinin kitleleri bilgisizliğin karanlığından kurtarmaya kalkıştığında, onlann çok katı bir tepkisiyle karşılaşacağın açıkça dile getirmiştir: "Bu adam onları çözmeye, yukarıya götürmeye kalkısınca, ellerinden gelse, öldürmezler mi onu?-Hiç §̧aşmaz öldürürler." Bkz.: Devlet, op. cit., 517 a.

${ }^{78}$ La Boétie'nin bir tyrannicide övgücüsü olarak tanunmasına yol açan en önemli etken, huguenot'ların Söylev'i, bu ve buna benzer bölümlere ağırlık vererek yajımlamıs olmalarıdır. 